\author{
Luxembourg Income Study \\ Working Paper No. 235 \\ The 1990s in Latin America: \\ Another Decade of Persistent Inequality
}

Miguel Szekely and Marianne Hilgert

December 1999 


\title{
The 1990s in Latin America: Another Decade of Persistent Inequality
}

\author{
by \\ Miguel Székely and Marianne Hilgert*
}

December 1999

\begin{abstract}
This paper argues that there is no country in Latin America where we can confidently say that income inequality improved during the 1990s. We document this fact for the 15 countries where comparable household surveys, covering most of the population, are available. What we observe are genuine distributive changes, which are being driven neither by differences in the characteristics of the data nor by the way in which the data is treated. In 10 of the countries, the lack of progress is driven by increases in inequality among the first nine deciles. In the remaining 5 , the reason is a greater concentration among the richest $10 \%$ of the population. We also observe that in 7 countries, the dynamics among individuals with 14 years or more of schooling are the main reason why income distribution has not improved in the 1990s. However, the lack of progress in income distribution is not exclusive to this region. We compare Latin America internationally and find that, with few exceptions, inequality has increased less in this region than in developed countries and in Eastern Europe.
\end{abstract}

Keywords: Inequality, distribution, income sources, Latin America.

JEL Classification: D31, O12, O54.

\footnotetext{
* The authors are at the Research Department at the Inter-American Development Bank (e-mail: miguels@iadb.org and marianneh@iadb.org). We thank Jose Antonio Mejía for support and advice regarding data, and Sam Morley for useful discussions. The opinions expressed in this paper are the authors' and do not necessarily reflect those of the Inter American Development Bank or its Board of Directors.
} 


\section{Introduction}

This paper argues that there is no country in Latin America where we can confidently say that income inequality improved during the 1990s. Apart from documenting this fact by using household survey data for the 15 countries in the region with information representative at the national level, ${ }^{1}$ we pursue two other objectives. First, we verify if what we observe are genuine distributive changes, or if they are being driven by differences in the characteristics of the data or by the way in which the data is treated. Secondly, we explore what kinds of individuals and what kinds of incomes are driving the shifts that have taken place.

Studying the Latin American case is especially relevant for at least three reasons. The first is that it is the most unequal region in the world, and the changes in the 1990s give some indication of prospects for the future. The second is that the 1990s have been years of economic recovery and macro stability, as compared to the "lost decade" of the 1980s, which was characterized by high economic volatility and stagnation, and by a sharp deterioration in income distribution. Macroeconomic volatility and inflation usually have larger negative effects on the poor, but it is still not clear if a more stable environment leads to reductions in inequality or simply to a deceleration or an end of the deterioration. ${ }^{2}$ Latin America is a good case to verify if there is a tendency for income distribution to improve after adverse macro conditions. This is important in light of the recent financial turmoil in East Asia, and of the unstable macroeconomic environment in several Eastern European countries. One of the best examples of why stable economic conditions do not necessarily imply improvements in the distribution is inflation. It is well known that high inflation rates affect the poor more because they do not have access to income smoothing mechanisms and because their incomes are more closely tied to minimum wages, which tend to deteriorate in these conditions. However, if inflation is

\footnotetext{
${ }^{1}$ As explained later, the only exception is Uruguay, where surveys cover around $90 \%$ of the total population in the country.

${ }^{2}$ There is a large list of works documenting deterioration in the distribution of income during recession, volatility and stabilization. One recent example is the collection of country studies in Ganuza, Taylor and Morley (1998).
} 
controlled, this normally means that the additional pressure on inequality will be released. Inequality will not continue to grow, but there is no reason to expect that it will decline.

The third reason is that during the 1980s the Latin American economies initiated an intense process of economic reform. ${ }^{3}$ These kinds of measures imply an intense reallocation of resources in the economy that is likely to have short-term and longer-term effects over income distribution. Since several Eastern European economies are going through the initial phases of the same process at the moment, it is of interest to know if there is a tendency for distribution to improve or worsen during or right after the implementation of reform.

The paper is divided into five sections. Section 1 documents the changes in inequality in Latin America in the 1990s by using 49 household surveys from 15 countries, and compares them with changes in countries of other regions in the world in recent years. In all cases inequality is estimated directly with the micro data from household surveys. Section 2 verifies if our impression about the changes in inequality is modified when accounting for differences in geographic and income source coverage. Section 3 checks for the robustness of the changes to the use of different assumptions about adult equivalence scales, economies of scale in consumption, treatment of missing and zero values, and the use of alternative inequality measures. Section 4 explores what's behind the changes, but still with the sole idea of illustrating what aspects of distribution have been changing, rather than explaining the causes of the shifts. Section 5 concludes.

\section{Changes in Inequality in the 1990s}

To explore the dynamics of income distribution in Latin America in the 1990s we process the micro data in 49 household surveys for Bolivia, Brazil, Chile, Colombia, Costa Rica, Ecuador, El Salvador, Honduras, Mexico, Nicaragua, Panama, Paraguay, Peru, Uruguay

\footnotetext{
${ }^{3}$ See IADB (1997).
} 
and Venezuela. ${ }^{4}$ These countries cover $90 \%$ of the total population in Latin America (see Appendix tables A.1 and A.2 for a description of the data), and to our knowledge they constitute the most comprehensive and up-to-date comparison for the Latin American region for the 1990s. The specific countries and years analyzed are selected under two criteria. The first is that the countries should have surveys that are nationally representative. The only exception we make is Uruguay, where household surveys are restricted to urban areas but still include more than $90 \%$ of the country's population.

We apply this strong restriction to assure that a sufficiently large proportion of the population is covered. Focusing on the urban distribution due to the lack of national data in countries with large rural populations may give a misleading impression of the direction and the size of a distributive shift. $^{5}$ Restricting the analysis to nationally representative information also guarantees that composition effects due to migration do not drive the changes we observe. By imposing this restriction, the number of data points we are left with is considerably reduced since countries with a long tradition of producing household surveys (to which we have access) are left out. One notable case is Argentina, where most of the surveys for the 1990s refer only to Gran Buenos Aires, or at best to other urban areas, but typically cover less than $70 \%$ of the population of the country. In some cases this restriction considerably shortens the period we are able to analyze. For instance, Bolivia, El Salvador, Ecuador and Paraguay have long series of urban surveys, but since they cover less than $50 \%$ of the total population the observations for those years have also been excluded from this study. Thus, for these countries, we restrict the comparison only to the years where a nationally representative survey is available to us.

The second and most important requirement is that the series of household surveys for the 1990s be strictly comparable within each country in terms of questionnaires, sampling techniques, and institutional origin. ${ }^{6}$ We do this to guarantee that what we observe are

\footnotetext{
${ }^{4}$ Some of these surveys where obtained through MECOVI, a program sponsored by the Inter American Development Bank, the World Bank, and ECLAC to collect and organize the existing household surveys in Latin America and to promote the implementation of new surveys. The rest of the surveys were obtained directly through country statistical offices.

${ }^{5}$ We illustrate this in Section 2.

${ }^{6}$ For a recent discussion of the importance of these aspects for comparisons over time, see Pyatt (1999).
} 
genuine distributive changes and not shifts caused by differences in the way in which the data is produced. For instance, in the case of Venezuela, household surveys are available for each year since 1990. We only use two of those surveys because the questionnaire and the instruments used to capture the information changed in 1994. Thus, the only surveys that are strictly comparable are those held either before 1994 or from 1995 on. $^{7}$ This restriction also implies dropping the Dominican Republic from our sample. This country has surveys for 1992 and 1996, but since the surveys have different objectives and questionnaires we do not consider them. ${ }^{8}$

It is important to bear in mind that with these two strong restrictions we guarantee comparability within the countries included in the study, but cross-country comparability is not guaranteed. Some of the differences become apparent in the following sections. ${ }^{9}$

Our 49 observations for Latin America are plotted in Figures 1, 2 and $3 .^{10}$ In Figure 1 we present the 8 cases where there is a statistically significant increase in the Gini coefficient between the first and last observation. The largest increases between the two end-points are observed in El Salvador, Nicaragua, Peru and Venezuela. ${ }^{11}$ Among the countries with

\footnotetext{
${ }^{7}$ The exceptions we make are one survey for Peru and two surveys for Honduras. The 1991, 1994 and 1997 Peruvian surveys are nationally representative, but the 1991 survey excludes the geographic areas of Costa Rural, Selva Urbana and Selva Rural, which account for 16\% and 18\% of the total population in 1994 and 1997, respectively. Throughout this work, we do not restrict the 1994 and 1997 samples to the same geographic areas as 1991 mainly because of the loss of information that this conveys. However, we check if our conclusions about the changes in inequality in Peru are modified when restricting the last two surveys to the geographic areas covered in 1991, but none of them is modified. In fact, the Gini coefficient computed with and without these geographic areas in 1994 and 1997 is not statistically significantly different from the Gini for the whole population. In the case of Honduras, the first three surveys we use are strictly comparable. The 1998 survey is identical except for the fact that it includes additional questions in the questionnaire to capture non-labor incomes. We have used the four surveys for our analysis and in Section 2 we show that the conclusions about the changes in inequality in this country hold when we only use the incomes that are strictly comparable throughout.

${ }^{8}$ The 1992 data is from a consumption survey, while the 1996 data is from a labor force survey. The income sources covered, the timing, the sampling technique and the objectives of each are different. We do not know if, when they are compared, the differences reflect real changes in inequality or if they are only reflecting differences in the way in which the data is produced.

${ }^{9}$ Székely and Hilgert (1999) present a detailed discussion of the differences across countries.

${ }^{10}$ We end up with 5 observations for Colombia, and Costa Rica, 4 for Brazil, Chile, Honduras, Mexico, and Uruguay, 3 for El Salvador, Panama and Peru, and 2 for Bolivia, Ecuador, Nicaragua, Paraguay and Venezuela.

${ }^{11}$ As mentioned previously, national household surveys for Venezuela are available for years previous to 1995. We have not used this information here because the data is not comparable with the surveys for 1995 and 1997 (the main difference is the change in the questionnaire), although we do have access to household
} 
more than two observations, we distinguish three patterns. First, in El Salvador, Panama and Peru inequality grows continuously throughout the period. Secondly, in Brazil and Uruguay, most of the deterioration took place during the early years of the decade. Thirdly, in Honduras there was a reduction in the early years of the decade, and a sharp deterioration thereafter.

Figure 2 presents the 6 countries where there is no statistically significant change in the Gini coefficient between the two end points of the 1990s. They are Bolivia (where the comparison is only available for 1996 and 1997), Chile, Colombia, Costa Rica, Ecuador and Mexico. Colombia and Chile are the only cases where the Gini shows some variation between the first and last observation. In Colombia there is a considerable increase in inequality between 1991 and 1993, and then a decline that fully compensates for the deterioration. In Chile there is a decline between 1990 and 1992, which is fully compensated by an increase in 1994 and 1996.

In Figure 3 we include Paraguay, which is apparently the only country where inequality declined (the figure has the same scales to facilitate the comparison). The solid line in the figure shows that that there is a substantial reduction in the Gini coefficient (of about 5 points) between 1995 and 1998. We present this country separately not only because it is apparently the only one where inequality decreased, but also because the 1995 survey, although comparable with 1998, is quite peculiar. As shown by Székely and Hilgert (1999), the high value of the Gini coefficient for 1995, which actually places the country as one of the most unequal in the world, is totally driven by a single outlier observation (out of a sample of around 22,000) with an income of US\$132,000 per month. This is an implausibly high figure for Paraguay, and it is actually the highest income captured by any of the household surveys in the 18 Latin American and the Caribbean countries with available data. The second highest income in the survey is eleven times smaller. Figure 4 plots all the incomes of the 1995 and 1998 surveys (in real terms and in the same scale)

surveys for Venezuela for 1989 and 1993. The Gini indexes computed from those data are .44 and .43, respectively. Including them in the picture would lead to the conclusion that inequality in this country increased by even more than is apparent in Figure 1, but this conclusion should be taken cautiously because the surveys are not strictly comparable. 
and illustrates more clearly the degree to which this observation is an outlier. As explained by Cowell and Victoria Feser (1996), these kinds of observations are normally regarded as "contamination" in the data and in the literature for developed countries it is standard practice to eliminate them from the sample. The dotted line in Figure 3 presents the change in the Gini coefficient after excluding the highest observation in both years, and shows that our impression about the change in inequality in Paraguay between 1995 and 1998 is totally driven by this single outlier in 1995. After excluding the top observation from each sample, there is no statistically significant change between 1995 and 1998.

Therefore, we can confidently say that none of the 15 Latin American countries examined here show distributive progress in the 1990s. In the only case where there is an apparent improvement, the conclusion depends on a single outlier observation that is not very reliable, and which perhaps is better described as "contamination" in the data. ${ }^{12}$

\section{Comparisons with Previous Decades}

In a recent paper, Londoño and Székely (2000) (LS) show that the Gini index in Brazil, Honduras, Panama, Peru and Venezuela increased during the 1980s. According to our results, the 1990s have experienced a continuation of this trend, although there seems to

\footnotetext{
${ }^{12}$ To our knowledge, the only two other works examining changes in inequality in a number of Latin American countries in the 1990s are Wodon et al. (1999) and ECLAC (1998). Wodon et al. use household survey data for 12 countries, but five of them have only urban coverage and large rural populations. The other two (the Dominican Republic and Venezuela) have data representative at the national level, but the series of surveys are not strictly comparable over time. The six countries where the authors use the same data as ourselves are Brazil, Chile, Colombia, Honduras, Mexico and Uruguay. The trend observed in the aforementioned study for these countries is very similar to our results. Nevertheless, the conclusions on the changes during the 1990s are not exactly the same as in this study for the cases of Honduras, Colombia and Uruguay, but this is only because Wodon et al. cover a shorter time-span (their analysis stops in 1996 for these countries), and do not consider the shifts observed up to 1997 or 1998, which are quite important, especially for Honduras and Uruguay. Comparisons with the ECLAC study are more difficult for four reasons. First, ECLAC only reports income distribution measures for urban and rural areas separately, so it is not possible to draw conclusions about the evolution of inequality at the national level. Second, the study does not specify which household surveys were used for the computations, so we do not know whether the information is comparable over time within each country. Third, the methodology, and in particular, the adjustments to National Accounts, are not explained or documented, so we do not know if there is comparability even between the Gini for urban areas they present and those presented later in this document. Fourth, for Bolivia, Colombia and Paraguay, the results refer only to large metropolitan areas that do not cover the whole urban population.
} 
be a slight deceleration in the deterioration. ${ }^{13}$ Londoño and Székely only consider countries with surveys in the 1980 s that are nationally representative, so they do not include information for El Salvador, Nicaragua, and Uruguay, which also appear in Figure 1. However, for Uruguay we do have a previous survey for 1981 with the same geographic coverage as the later surveys. We compute the Gini coefficient for this year and find that inequality declined from .4329 in 1981 to .4064 in 1989 . According to our calculations, the Gini index for Uruguay for 1997 is .43, so the slight improvement in the 1980s in this country seems to have ended during the present decade.

With respect to the countries in Figure 2, Londoño and Székely show that there was a sharp increase in inequality during the 1980s in Mexico and Chile. In the 1990s, inequality has remained at practically the same high level in these countries. Colombia and Costa Rica are the only countries in our sample where Londoño and Székely show that the Gini coefficient declined during the 1980s. During the 1990s, distribution has not continued to improve in any of these cases.

\section{Comparisons with Countries in Other Regions}

To place these changes in a wider context, we access household survey data from the Luxembourg Income Study for two points in time for 17 countries from outside the Latin American region, as well as several Socio-Economic Surveys for Thailand. We do this to verify whether the lack of distributive progress in the 1990s is exclusive to the Latin American region or if it is a more widespread phenomenon. Table 1 presents the results and includes the change between the first and last survey for each of the Latin American countries in our sample. ${ }^{14}$ The Gini coefficients refer to the distribution of household per capita income.

\footnotetext{
${ }^{13}$ Strict comparability between the Londoño and Székely country estimates and those presented here is not guaranteed, even though they all refer to countries with nationally representative surveys. Thus, these comparisons should be taken cautiously.

${ }^{14}$ Note that the comparison does not refer to the same years for each country. Note also that the last year in the comparison for the Latin American countries is generally closer to 1998 than in the other regions. To make the Gini coefficients more comparable, we compute inequality in the non-Latin American countries by using the full sample of individuals (excluding domestic servants and boarders), but we drop missing and zero values. In Table 1 we use income, rather than consumption, because most surveys report only
} 
Of the 32 countries in the table, there is only one case (Thailand) where there is a statistically significant reduction in the Gini index in the 1990s. On average, the smallest yearly increase is actually observed in the group of countries comprised by Latin America. They are followed by North America (note, however, that the change in the United States is much greater than in Canada) and Western Europe. Eastern Europe is the region with the sharpest deterioration.

With respect to individual countries, the largest yearly increases (in Gini points) are registered in El Salvador (0.018), Poland (.017 points), Hungary (.015), Venezuela (.013) and Italy (.013 points). With the exception of El Salvador and Venezuela, the increase in the rest of the Latin American countries does not deviate considerably from the pattern in countries found outside the region. In fact, for most Latin American countries, the yearly change in inequality during the 1990s has been smaller than in the US.

It should be noted that the Eastern European countries that register the largest increases in inequality are still going through a period of economic liberalization and macroeconomic instability, which is similar to the macro context during the second half of the 1980s in Latin America. In contrast, the latest observations for Taiwan and Thailand are several years before the recent financial crisis in East Asia. Therefore, we are comparing changes in inequality post-crisis and during reform in Latin America, with inequality during crisis in Eastern Europe, with inequality pre-crisis in East Asia, and with inequality during mild, but positive, growth in industrial countries. More recent data for South East Asia and Eastern Europe would perhaps change this picture.

income. For a more detailed analysis of changes in inequality in developed and Eastern European countries, see Gottschalk and Smeeding (1998). 


\section{Changes in Inequality and Survey Characteristics}

Results such as those presented in Figures 1 to 3 are commonly used to evaluate economic performance and may influence our impression about the effectiveness of the policies that countries pursue. Usually, countries where income distribution improves over time are regarded as successful, while the contrary occurs for countries where inequality increases. In this section we explore whether, even after restricting the sample of countries to those that have strictly comparable surveys, differences in survey characteristics or some other aspects of the surveys are driving the changes we observe across countries.

First, we turn to changes within each country. Even though the Gini indexes in the first column of Table 2 are computed from household surveys that are strictly comparable over time, the sample from which they are drawn can change in subtle ways, thereby distorting the picture of the changes in inequality. For instance, even though the survey questionnaire is strictly comparable, there may be changes in the sampling frame that modify the weight of some population groups, and therefore modify the value of the Gini coefficient even if there is no real distributive shift. Appendix Table A.2 shows the census used as the frame for the design of each of the surveys. In most cases, the frame is the same for all observations, but in Chile, Mexico, Nicaragua and Peru, it changes in some years. In Mexico it actually changes twice. In all these cases the difference is in the first years considered, so any conclusion driven by the early part of the decade should be taken with more caution.

A related issue is the size of the sample in each survey. On the one hand, larger samples improve the precision of any estimate, and on the other, by increasing population coverage, they might include a wider variety of socioeconomic groups. Since improvements in terms of the precision or in the increases in coverage do not have any clear effect on inequality estimates, we can do little more than document them. Table A.2 in the Appendix presents the sample sizes as well as the standard error of each 
observation and shows that in Chile, Colombia, Honduras, El Salvador, Uruguay, and Venezuela there are considerable shifts in some years.

With respect to differences in survey characteristics across countries, the two most important issues are income source and geographic coverage. We now turn to assess their importance.

\section{Differences in Income Source Coverage}

One of the main differences across countries is the degree to which household surveys capture the range of possible income sources. The most complete surveys capture nonmonetary incomes, labor incomes, income from capital, government transfers, property rents, and other incomes. As shown in Appendix Table A.2, most surveys capture some non-labor incomes, but it is common to capture these sources through a single question in the questionnaires rather than gathering information on each of them separately. This difference undoubtedly reduces the precision of the estimation of non-labor incomes. It can also be seen that there are important differences in the coverage of non-monetary incomes.

Table 2 presents in the first column the Gini coefficient estimated in a conventional way for Latin America - that is, using per capita income and dropping all zero and missing values - with the most complete definition available in each case (these are the observations plotted in Figures 1 to 3 ). The second column presents the Gini for labor incomes, including labor income from self-employment. This is the income source with the highest degree of comparability across countries and over time. If we restrict our comparison to this source, we would conclude that in 11 cases inequality increased during the 1990s (comparing the first and last points). In Bolivia, Costa Rica and Ecuador, the change is not statistically significant. Paraguay is the only country where there is a reduction, but, as shown in Figure 4, this conclusion is totally driven by a single outlier observation in the survey. 
Therefore, if we restrict the Gini coefficient to measure inequality by using the same comparable income sources in all cases, some conclusions change. Chile, Colombia, and Mexico, which apparently have a better record in terms of income distribution in the 1990s, now appear to have significant increases in inequality, even similar to those observed in Honduras and Nicaragua. The reason why the first three countries at first glance have a better record than the last two is simply that their household surveys cover other income concepts that apparently have been better distributed than labor incomes.

\section{Differences in Geographic Coverage}

Since our sample of countries includes one where the surveys are not nationally representative, it is also of interest to compare the change in urban areas only, which is the only way of guaranteeing geographic comparability. The last columns of Table 2 present the Gini for urban and rural areas separately, as well as the relation between the average urban and rural incomes, and the proportion of urban population. ${ }^{15}$ According to the results, there are several cases where our impression of the change in inequality would be modified by restricting the samples to urban areas. In Bolivia, Chile, and Colombia, urban inequality increases during the 1990s, while in Costa Rica, Ecuador and Mexico urban inequality declines between the first and last observation. Interestingly, these are the six countries where there was no statistically significant change in the Gini coefficient for the whole population. Thus, the conclusions change if we restrict our comparison to the same geographic areas for all 15 countries. Most importantly, this comparison reveals that in countries where the rural population is relatively large (see the last column of the table), focusing only on urban areas, due to the lack of national household surveys, can give a totally misleading impression of how inequality has changed.

\footnotetext{
${ }^{15}$ We present the data in this way, rather than through the traditional decomposition of the change in inequality into between and within group effects (by using members of the General Entropy family of inequality measures), because our objective is to determine whether our impression of the change in inequality depends on the geographic area that the surveys cover. For Venezuela 1997, we do not have access to the variable indicating the geographic location of each observation. For this reason we do not separate the data.
} 
The differences between total inequality and urban inequality are the effects of the disparities within rural areas and the effect of differences between the average incomes of these two areas. Rural inequality increased in 7 out of the 13 cases where the comparison can be made. In Chile, Colombia and Paraguay it declined, and it remained practically unchanged in Costa Rica, Mexico and Panama. Differences between urban and rural areas have also changed quite significantly (see Table 2). In Bolivia, Ecuador, Honduras and Peru they had an inequality-reducing effect, while in Chile, Colombia, El Salvador, Mexico and Paraguay, they had the opposite impact. Restricting the comparison to urban populations ignores these important effects on distribution.

\section{Do the Conclusions Survive Some Robustness Tests?}

The Gini indexes in Figures 1 to 3 are computed by using income per capita as the welfare indicator and by dropping all missing and zero incomes. This is equivalent to assuming that there are no economies of scale in consumption, that each individual in the household has the same needs, and that all missing and zero values are unreliable observations and should be discarded. Although this is the standard way in which inequality estimates are computed in Latin America, ${ }^{16}$ there are equally valid alternative assumptions that could be used. In this section we check whether our conclusions depend on the specific methodological choices used so far. We also explore if the conclusions are robust to the choice of other inequality indexes.

\subsection{Economies of Scale and Adult Equivalence Scales}

As argued by Lanjow and Ravallion (1995), the assumption that there are no economies of scale in consumption is unrealistic because when an additional member joins the household it is not necessary to duplicate many of the basic expenditures, such as infrastructure. There can even be economies of scale in food production and

\footnotetext{
${ }^{16}$ Londoño and Székely (2000).
} 
consumption. Income per capita is computed by dividing total income $(y)$ over the number of individuals in the household $(n)$, but it can also be expressed as $y / n^{\alpha}$, where $\alpha$ is a parameter indicating the extent to which there are economies of scale. Per capita income is obtained when $\alpha=1$.

Unfortunately, there is no convincing theoretical argument to decide what the value of $\alpha$ should be within different contexts. One option, which we pursue here, is to define a range of values for the parameter, with which the sensitivity to the particular choice can be verified. For the purposes of this work, we choose four values for $\alpha: .975, .95, .925$ and .9 , which still imply rather conservative assumptions about economies of scale. If we assume the most extreme of these values, $\alpha=.9$, a household of 5 members (the average in Latin America) is equivalent to a household size of 4.2 individuals. This yields a greater income for each member as compared to the assumption that $\alpha=1$.

The first column in Table 3 presents the Gini index calculated using $\alpha=.9$ (we do not present the results using other values of the parameter for brevity and because they show smaller variation). There are four countries where our conclusions change when we allow for economies of scale in consumption. In Chile and Ecuador inequality increases rather than remaining constant, although the shift is only statistically significant in Chile. In Uruguay, rather than an increase, there is no statistically significant change, while in Costa Rica inequality declines rather than remaining constant. For the rest of the countries, our conclusions remain unchanged when using the range of parameters mentioned above.

Apart from the possible existence of economies of scale, it is normally argued that different individuals have different needs. For instance, in the analysis of income distribution in developed countries, equivalence scales are widely used to adjust for differences in needs by age. ${ }^{17}$ In Latin America, the use of equivalence scales has been much more limited mainly because adequate estimates are not readily available. To check for the robustness of the results to adjusting the data for differences in needs, we use two 
equivalence scales. The first is the "Amsterdam" scale in Deaton and Muellbauer (1980), which has been widely used in developed countries, and the second is a recent scale estimated by Contreras (1996) with data from Chile. The second column in Table 3 presents the results using the equivalence scale by Contreras, which is the one under which the Gini presents greater variation. ${ }^{18}$

If, rather than focusing on the conventional Gini, we allow for the use of equivalence scales, our conclusions from Section 1 change only marginally. In Ecuador there is a slight increase, rather than a stable Gini, while in Mexico there is a slight decline instead of no change.

\subsection{Treatment of Missing and Zero Values}

So far we have dropped missing and zero incomes from the sample. In the few countries that document how these cases are handled, most proceed in the same way. ${ }^{19}$ Usually the justification for doing so is that these observations are unreliable and introduce more noise than signal into the measurement of inequality. According to Juster and Smith (1998) missing values tend to be correlated with capital incomes, and are generally due to the reluctance of the rich to disclose their wealth. In the case of zero incomes, it is not quite clear if they are associated with specific income sources, income levels and socioeconomic characteristics, or if they represent a precise and reliable answer to survey questions at all. This is a potentially important issue in Latin America because, as shown in Table 3, the proportion of missing and zero incomes varies not only across countries, but also within the same country in many cases. The only countries where they are negligible are Mexico, Peru and Uruguay. But in Nicaragua, Costa Rica, Bolivia and El Salvador they account for more than $10 \%$ of the observations in the whole household survey for some years.

\footnotetext{
${ }^{17}$ See, for instance, Gottschalk and Smeeding (1997).

${ }^{18}$ This equivalence scale is taken from Ferreira and Litchfield (1997), who adjust the original scale by Contreras. For the typical 5-member household in Latin America, applying the Contreras equivalence scale implies reducing household size from 5 to 3.5 .

${ }^{19}$ Londono and Székely (2000).
} 
Excluding zero and missing values from the computation of the Gini is, however, only one among several options. We may also choose to believe that individuals reporting zero income are providing reliable information or, alternatively, we can impute incomes for zero income respondents rather than discarding them. For the purposes of this work we tried several combinations of dropping and imputing missing and zero values one at a time. The option under which the greatest variation was identified is the case where missing values are imputed and zero incomes are taken at their face value. For the imputations we follow a two-step procedure. The first step consists of estimating income regressions for each income source separately, where each individual's income is the dependent variable, and the independent variables are all personal and household characteristics. The coefficients are used to predict each income-earner's income for that source, including non-respondents. The second step consists of ranking all income earners of the source in question (including non-respondents) according to their predicted income. For non-responses, the error term is calculated by averaging the residual of the observation immediately above and below, and the total imputed income corresponds to the predicted plus the estimated residual. Household incomes are added up after the procedure. $^{20}$

The fourth column of Table 3 presents the Gini coefficient for each year by treating missing and zero incomes in the way just described. The results are quite striking. Now, instead of having 8 countries with a statistically significant change in inequality during the 1990s, we have 10 cases. We now have 5 countries where the shift is not significant, but the countries in this group are very different from those in Figure 2. Finally, there is not even one case, including Paraguay, where inequality appears to decline in a statistically significant manner. Bolivia, Chile, Colombia, and Ecuador are the countries where the pattern is modified from no shift to a significant increase. Nicaragua and Panama are the two cases where the original Gini increased, but after imputation of missing incomes and taking zero's at their face value the distribution remains unchanged.

\footnotetext{
${ }^{20}$ Brick and Kalton (1996), Kalton and Kasprzyk (1986), and Rubin (1987) review other methods for dealing with missing values.
} 
In Paraguay, rather than having a sharp decline (although driven by a single outlier), there is no statistically significant change.

\subsection{Use of Different Indexes for Measuring Inequality}

Undoubtedly the Gini coefficient is the most commonly used measure of inequality, but there is a long list of equally acceptable alternative measures. The main difference is that different measures apply different weights to different sections of the distribution (for instance, the Gini applies more weight to the middle). The family of Generalized Entropy Inequality measures $(E)$ explained by Cowell and Jenkins (1995) are some of the most transparent measures in the sense that they explicitly allow different weights to be applied to different sections of the distribution through the choice of a simple parameter. $^{21}$

Columns 5 and 6 in Table 3 show changes in inequality by using two members of the entropy family of indexes: one that applies greater weight to changes at the lower tail of the distribution $(\beta \cong-1)$, and another that applies more weight at the top ( $\beta \cong 1$ ). According to these results, our conclusions on the change in inequality for Costa Rica, El Salvador, Honduras, Nicaragua, Peru, Uruguay and Venezuela hold for either of these two indexes. In the case of Brazil and Panama, the bottom-sensitive index declines while the topsensitive index and the Gini increases. Overall inequality measured by the Gini in these countries increases because the improvements at the bottom are counterbalanced by the greater concentration at the top of the distribution.

Perhaps the most interesting result is that, for five out of the six countries where the Gini remains stable during the 1990s (see Figure 2), the use of an alternative index leads to the conclusion that inequality actually increased. In Bolivia and Colombia the conclusion of

\footnotetext{
${ }^{21}$ These indexes take the following form:

$$
E=1-\left[\left(1 / n_{x}\right) \Sigma_{i=1}\left(y_{i} / \mu_{x}\right)^{\beta}\right]^{(1 / \beta)}
$$

where $\beta$ is a parameter that can be assigned any real value, $n_{x}$ is the size of the population, and $y_{i}$ and $\mu_{x}$ are the income of each individual, and the average income of population $x$, respectively. Specifying a high
} 
stability is reversed by the use of a bottom-sensitive index, while for Chile, Ecuador and Mexico the top-sensitive index yields a deterioration in the distribution of income.

Thus, in 7 out of the 15 cases, our impression of changes in inequality depends on the way in which we choose to summarize income distribution. In Table 5 we restrict the choice of measure to only two entropy indexes, ${ }^{22}$ but in Appendix Table A.3 we present some other commonly used summary inequality measures. The first column shows the income ratio of individuals at the top and bottom $10 \%$ of the distribution, respectively. The second compares the top $10 \%$ with the bottom $30 \%$, while the third compares the richest and the poorest quintile. Interestingly, in 12 countries - including Chile, Colombia, and Ecuador, where the Gini remains unchanged - the income gap between the poorest and richest $10 \%$ expands. It only declines in Costa Rica, Mexico and Paraguay (although in the latter country the result is driven by the outlier observation at the top of the distribution), and in Mexico the reduction is only marginal. The differences between the top $10 \%$ and bottom $30 \%$ expand in 11 countries, but the gap does not widen as much as in the previous comparison. The same applies to the comparison of the top and bottom quintile. The income gap expands in most cases, but the change is only important in Brazil, Ecuador, El Salvador, Honduras, Nicaragua, Peru and Venezuela.

For a more general approach we perform first order stochastic dominance tests with the micro data to determine whether the whole distribution for the first year is unambiguously more equal than the distribution for the last year available. The last column in Table 3 shows the year that Lorenz dominates (is more equal) the distribution of the current year (blank spaces indicate that there is no first order stochastic dominance between the year in question and other year). The test is only performed for the endpoints for simplicity. In Bolivia, Brazil, Chile, Costa Rica, Mexico, Panama and Uruguay, the Lorenz curves for the first and last years intersect at some point, so the direction of the change in inequality is ambiguous. In the rest of the countries, the last

positive value yields an index that is more sensitive to redistributions at the upper tail of the distribution, while a negative value yields indices attaching larger weights to changes at the lower tail. 
year is dominated by the first, so there is an unambiguous increase in inequality, although the shift is not always statistically significant.

\section{What is Driving the Changes?}

This section explores what is driving the changes in inequality in Latin America during the 1990s. First we analyze the role played by some specific socioeconomic groups, and then we focus on the role of the different income sources. We stress that our objective is not to explain the shifts, but rather to provide an idea about what aspects of the data are driving the lack of distributive progress.

\subsection{Are the Changes Due to Greater Concentration Among the Rich?}

We are especially interested in determining which parts of the distribution have been shifting in Latin America in the 1990s because theoretically it is not clear if, after periods of macroeconomic instability and economic reform, there are specific groups of the population who are better able to take advantage of the opportunities that are being generated. To examine this issue, we first focus on the influence of the richest sectors of the population and, secondly, we try to establish the effect of other groups characterized by their schooling.

A simple way to verify if the lack of distributive progress is due to a concentration of resources among the richest individuals is to re-compute the Gini coefficient by truncating the distribution at the top. ${ }^{23}$ Specifically, we estimate inequality by excluding

\footnotetext{
${ }^{22}$ In fact, we computed the entropy measures with a wide variety of values for the parameter $\alpha$. We only present the cases for $\beta \cong 1$ and $\beta \cong-1$ here because these are enough to make the point that different measures may lead to different conclusions.

${ }^{23}$ The standard way to measure the influence on a change in inequality of a certain portion of the population is to classify the population according to certain personal characteristic and to decompose the change in inequality into the effect of the redistribution within and between groups, respectively, and the effect of population shifts from one group to another (see, for instance, Mokerjee and Shorrocks (1982). We do not use this method here because we are interested in one very specific subgroup.
} 
the richest 10 households, the richest $1 \%$ of the population, the richest $2 \%$, the richest $5 \%$ and the richest $10 \%$, respectively, and verify if the direction and magnitude of the distributive shift is similar to the results in Table 2. Table 4 presents the results.

In Bolivia, Chile, Costa Rica, El Salvador, Honduras, Uruguay and Venezuela, truncating the distribution at the richest $10 \%$ or above does not make much of a difference. The change in inequality in these cases is practically the same as in Table 2 . In the last four countries there is a raise in the Gini, which is therefore caused by shifts among the first 9 deciles of the population.

In six out of the remaining eight countries, changes in inequality in the 1990s are strongly influenced by the greater concentration among the richest $10 \%$ of the population. For instance, in Brazil and Peru the increase in inequality documented in Table 2 is mainly due to the income gains of centiles 90 to 95 . We arrive at this conclusion because when truncating the distribution at the top $10 \%$ there is a much smaller deterioration. But if the distribution is truncated at the top 5\% the increase is much more considerable and very similar to the change in Table 2. In Nicaragua and Panama the situation is similar, although the income concentration that drives the increase in inequality is observed at centiles 95 to 98. The shifts in Mexico and Paraguay have the same features, although the main distributive effect is observed higher in the distribution. In Mexico, inequality among the first 98 centiles declined in a statistically significant way, but the greater concentration among the richest $2 \%$ resulted in no change in the overall distribution. The case of Paraguay is already documented in Figure 3. Excluding the highest observation in this survey changes the conclusion about the evolution of inequality. Table 4 confirms this.

Londoño and Székely (2000) find that most of the increases in inequality in Latin America during the 1980 s are precisely due to a higher concentration at the top decile. Therefore, the results for these six countries can be regarded as a continuation of the trend. 
In the remaining two countries, Ecuador and Colombia, the top $10 \%$ also has a significant influence on changes over time, but in these cases the dynamics are quite the opposite. In Ecuador, the overall Gini does not change, but if the distribution is truncated at the $95^{\text {th }}$ centile, the conclusion would be that inequality increased. Thus, the change in income among the two richest centiles actually contributed to improve the overall distribution. Colombia is a similar case. Truncating the distribution below the ten richest households results in a considerable increase in the Gini. After including these households in the computation, the Gini presents no statistically significant shift.

As already mentioned, it is common in developed countries to truncate the distribution at the top (generally the top 1\%) and exclude it from the sample, because extreme incomes are regarded as less reliable. The main reason is that even if the richest individuals were willing to report all their income, it is difficult to determine their size with precision because they are usually derived from a variety of assets. Therefore, the first two columns in Table 4 could also be interpreted as an exercise where some of the observations that are suspected of having larger measurement error are excluded from the sample. The Gini with this truncation could be regarded as a "cleaner" comparison across countries. Under this interpretation, the first two columns of Table 4 would lead us to change our impression about how inequality has shifted in the 1990s in Chile, Colombia and Paraguay. Rather than having no change and a significant decline, respectively, we have a raise in the first two countries and no change in the third.

\section{Are the Changes Due to More Concentration Among the Most Educated?}

Another way of looking at the influence of specific subgroups is to divide the population according to years of schooling rather than by the position in the income distribution. This has an advantage in that most individuals in Latin America do not continue their formal schooling after age 20 and it is therefore possible to roughly follow about the same group of individuals across surveys. ${ }^{24}$ Table 5 presents our estimations by

\footnotetext{
${ }^{24}$ There will be changes in composition due to the incorporation of individuals formerly below 20 in the first survey, but since we are not looking at long periods of time, these composition effects are not expected to be strong.
} 
excluding different groups of individuals at the top of the schooling (rather than the income) distribution. The first column excludes individuals over 20 years of age with at least 20 years of formal schooling (typically these individuals at least have post-graduate education). The second column excludes individuals with 18 years or more (with at least a college degree), the third column truncates the schooling distribution at 15 years (some college education), while the last column refers to the Gini index computed for individuals with at least 12 years (some post-secondary). The change in overall inequality is the result of the inequality within the group we are considering (those below each schooling threshold), plus the inequality among those in the subgroup excluded from the calculation, plus the inequality due to the difference in average income between the two groups. In Table 5 we are only considering the distribution within the specific group below the threshold.

In Bolivia, Brazil, Costa Rica, El Salvador, Honduras, Paraguay, Peru and Venezuela, the conclusion about the magnitude of the change in inequality remains practically unchanged after truncating the schooling distribution. In Colombia, Ecuador, Nicaragua and Uruguay, excluding all individuals with more than 14 years of school would lead to the conclusion that inequality declined in the first two (rather than remaining constant), and remained constant (rather than increasing) in the other two. Thus, the subgroup of individuals with more than 14 years of schooling exacerbates inequality. Their inclusion cancels out the improvements in the distribution among individuals with less education. In Chile and Panama, the same effect is observed but for individuals with more than 17 years of schooling. In Mexico, excluding all individuals with less than 19 years would lead to the conclusion that there was a significant decline in the Gini index. Thus, the dynamics among the most highly educated are driving the lack of progress in distribution.

\subsection{Which Income Sources are Behind the Changes?}

Now we ask which types of income sources have been behind the changes in inequality. We have already presented some information on this in Table 2, but to provide a more 
precise idea of the contribution of each source, we apply the decomposition suggested by Székely (1998). This method allows us to identify the effect that changes in the distribution within each source and changes in the factor shares have on total inequality. ${ }^{25}$

Table 6 presents the decomposition of the change between the first and the last year available for each country (Bolivia is excluded because all effects are negligible). We divide total income into four different sources: labor income for employees, labor income for the self-employed, non-labor income, and non-monetary income. The split of labor income into self-employment and employees is because presumably, one of the effects of economic reform is the creation of market opportunities, which could be reflected in a surge in self-employment.

In all cases but El Salvador, Honduras and Paraguay, the factor share effect, which accounts for changes in the relative weight of each income source, plays a minor role in the change in income distribution. In Honduras and Paraguay, the main effect is that the relative importance of labor income from self-employment increased during the 1990s. Since this source has a more unequal distribution than labor income for employees, the shift has a positive contribution to the increase in inequality. A similar situation arises in Mexico and Uruguay, although the factor share effect is much smaller. In the case of El Salvador most of the effect is driven by the increase in the importance of labor incomes for employees. The share of labor income for the self-employed also increased, and since these sources have a less egalitarian distribution the change contributes to increased inequality.

In all cases but El Salvador and Venezuela, there is a deterioration in the distribution of labor incomes for employees, which accounts for a major inequality increasing effect.

\footnotetext{
${ }^{25}$ The decomposition consists on expressing a change in inequality as: $\Delta I=\sum_{i=1} I_{k} \Delta \beta_{k}+\sum_{i=1} \beta_{k} \Delta I_{k}$
}

where $\mathrm{I}$ is overall inequality, $\mathrm{I}_{\mathrm{k}}$ is inequality within source $k$ and $\beta_{\mathrm{k}}$ is the income share of source $k$. The first term on the right hand side of the equation is the "factor share effect," while the second term is the "inequality effect." The equation is derived from Shorrocks (1982) and provides an exact decomposition that can be applied equally well to any inequality measure. 
There is also a strong inequality-reducing effect from the improvement in the distribution of labor income from the self-employed (two exceptions are Nicaragua and Colombia, where both effects are positive). These two shifts may be responding to the same incentives. The inequality-increasing effect may be reflecting a rise in the return to skills, while the negative effect from the self-employed may be associated with a displacement of individuals with relatively high incomes and education, who might have shifted toward the jobs with the highest remuneration among employees.

Non-labor incomes have had un-equalizing effects in all countries except for El Salvador and Venezuela. In these cases, the factor share and the inequality effect have contributed to reducing inequality, but the effect has been totally counterbalanced by the regressive effects of labor incomes from employees (and labor incomes from self-employment in El Salvador). In the rest of the countries, non-labor incomes have been part of the reason why inequality has failed to decline in the 1990s. It should be stressed, however, that non-labor incomes tend to be captured with lower precision than labor income. So, part of the reason why this source does not play a predominant role may simply be that household surveys are not able to register them appropriately.

Only five countries in the Table have information for non-monetary incomes, and even among these few cases there are differences in the definition of this source. ${ }^{26}$ In Colombia and Uruguay these sources have had a modest contribution to the increase in inequality, while in Chile and Peru they have been an important cause for the shift. In Mexico, non-monetary incomes have had a modest contribution in reducing inequality.

In sum, there is not a very clear pattern about the role that different income sources play over the changes in inequality. The only regularity is a substantial contribution of labor incomes of employees to the increase in inequality. This is to some extent counterbalanced by the improvement in the distribution of labor incomes from selfemployment.

\footnotetext{
${ }^{26}$ Specifically, in some cases only income in kind is included, while in others gifts and imputed rents are also accounted for.
} 


\section{Conclusions}

This paper uses 49 household surveys from 15 Latin America countries in order to explore what has happened to inequality during the 1990s. We restrict the comparison to the countries that have data that is representative at the national level, and to household surveys that are strictly comparable over time. This limits the number of countries and years, but there are two important advantages. First, since the surveys are national, we are sure that our conclusions apply practically to the whole population of each country, rather than to restricted subgroups, as is the case with surveys that only have urban coverage. Second, comparability assures that our conclusions refer to genuine distributive shifts, and not to "artificial" variation introduced by differences in the survey methodology over time.

We can confidently say that in the 15 countries where comparable national household surveys are available, income distribution has not improved in the 1990s. There are five cases - El Salvador, Honduras, Nicaragua, Peru and Venezuela - where inequality has definitely increased sharply. In 3 other cases, the Gini coefficient estimated in a conventional way also shows a statistically significant rise, but if inequality is measured with alternative inequality indexes (for Brazil and Panama), or economies of scale in consumption are allowed for (in Uruguay), inequality declines or remains constant.

There are six countries where there is no statistically significant shift in the Gini during the 1990s, when the coefficient is estimated in the standard way. However, if rather than discarding missing and zero incomes - which is quite standard in Latin America but not in other regions - we impute missing values and take zero incomes at their face value, the Gini for Bolivia, Chile, Colombia and Ecuador presents a statistically significant increase instead of remaining stable. Mexico is another case where there is apparently no shift, but if rather than using the Gini, a top-sensitive inequality index is employed, the conclusion is that there is a considerable deterioration in distribution. Costa Rica is the only country among these six where the conclusion of no shift during the 1990s is robust to the different ways of treating the data. 
The only country where at first glance there is a reduction in inequality in the 1990s is Paraguay. But this conclusion is totally driven by one outlier observation (among the sample of about 22,000) in the 1995 data, with implausibly high incomes. This outlier drives up the Gini for 1995, so when it is compared with 1998 it gives the impression of a substantial improvement in income distribution. Once this observation - which is perhaps better regarded as "contamination" in the data - is dropped, the conclusion is that there is no statistically significant change in this country as well.

Although consistency within each country is guaranteed by the use of strictly comparable surveys, there are still considerable differences across countries in the characteristics of household surveys. All of them include information for labor incomes, but there is wide variety in the coverage of other sources. If the comparison is restricted to the minimum common denominator (labor incomes), the conclusion is that inequality increased in 11 cases and remained unchanged in only 3. In Paraguay there is still a decline, but it is totally driven by the one outlier observation.

What is driving the lack of distributive progress? In Colombia and Ecuador the reason is that inequality among the first 98 centiles increased; the lower concentration among the richest $2 \%$ actually counterbalanced this effect, and this is why there is no shift overall. In Bolivia, Chile, Costa Rica, Ecuador, El Salvador, Honduras, Uruguay and Venezuela, the lack of progress is caused by an increase in inequality among the first 9 deciles of the population. In contrast, in Brazil and Peru the increase is driven by the income gains of centiles 90 to 95. In Nicaragua and Panama, the income concentration at centiles 95- 98 is the main force behind the increase, while in Mexico and Paraguay the lack of improvement is driven by income gains among the richest $2 \%$ of the population.

In terms of education groups, in Bolivia, Brazil, Costa Rica, El Salvador, Honduras, Paraguay, Peru and Venezuela the lack of progress cannot be attributed to the income gains of the most educated individuals. But in Colombia, Ecuador, Nicaragua, Uruguay, 
Chile, Panama and Mexico, the dynamics among individuals with 14 years or more of schooling are the main reason why income distribution has not improved in the 1990s.

As for income sources, the main force driving the lack of distributive progress is the deterioration in the distribution of labor incomes.

Does this mean that we should not expect major improvements in distribution in other regions, such as Eastern Europe, where countries have macro conditions similar to those of Latin America in the 1980s? Or that it is likely that the distribution will worsen in East Asia after the recent financial crisis, and that the trends will persist even with more stable macroeconomic conditions? When Latin America is compared internationally it turns out that, with few exceptions, inequality has increased less than in developed countries and Eastern Europe. But still, the evidence presented here leads us to think that the answer to these questions might be yes. 


\section{Bibliography}

Brick, J. M., and Kalton, G. 1996. "Handling Missing Data in Survey Research." Statistical Methods in Medical Research. 5 (2): 215-238.

Contreras, D. 1996. "Household and Individual Welfare: Evidence from Less Developed Economies." Los Angeles, United States: University of California, Los Angeles. Mimeographed document.

Cowell, F. and Jenkins, S. 1995. "How Much Inequality Can Be Explained: A Methodology and An Application to the USA.” Economic Journal. 102 (2): 421-430.

Cowell, F., and Victoria-Feser, M.P. 1996. "Robustness Property of Inequality Measures." Econometrica. 64 (1): 77-101.

Deaton, A., and J. Muellbauer (1980) "Economics and Consumer Behavior" Cambridge University Press.

ECLAC. 1998. "Panorama Social de América Latina." Santiago de Chile: United Nations Economic Commission for Latin America and the Caribbean.

Ferreira, F., and Litchfield, J. 1997. "Income Distribution and Poverty: a Statistical Overview." In: Chile, Poverty and Income Distribution in a High-Growth Economy: 1987-1995. Washington, DC, United States: World Bank.

Ganuza, E., Taylor, L. and Morley, S. 1998. Politica macroeconómica y pobreza en América Latina y el Caribe. Madrid, Spain: Mundi Prensa/UNDP/IADB/ECLAC.

Gottschalk, P. and Smeeding, T. 1997. "Cross-National Comparisons of Earnings and Income Inequality." Journal of Economic Literature. 35 (2): 633-687.

----. 1998. "Empirical Evidence on Income Inequality in Industrialized Countries." Working Paper. Mimeographed document.

Inter-American Development Bank. 1997. Latin America After a Decade of Reforms: Economic and Social Progress in Latin America. Baltimore, United States: Johns Hopkins University Press/IADB.

Juster, T. and Smith, J. 1998. "Enhancing the Quality of Data on Income and Wealth: Recent Development in Survey Methodology". Paper presented at the $25^{\text {th }}$ General Conference of The International Association for Research in Income and Wealth, Cambridge, United Kingdom.

Kalton, G. and Kasprzyk, D. 1986. "The Treatment of Missing Survey Data." Survey Methodology. 12 (1): 1-16. 
Lanjouw, P. and Ravallion, M. 1995. "Poverty and Household Size." Economic Journal. 105 (433): 1415-1434.

Londoño, J.L., and Székely, M. "Persistent Poverty and Excess Inequality: Latin America 1970-1995." Journal of Applied Economics. Forthcoming 2000.

Mookherjee, D., and Shorrocks, A. 1982. "A Decomposition Analysis of the Trend in UK Income Inequality.” Economic Journal (92): 886-902.

Pyatt, G. 1999 “The Distribution of Living Standards within Countries: An Historical Perspective on a New International Data Base." The Hague, The Netherlands: Institute of Social Studies.

Rubin, D. 1987. Multiple Imputation for Nonresponse in Surveys. New York, United States: John Wiley and Son.

Shorrocks, A. 1982. "Inequality Decomposition by Factor Components." Econometrica. 50 (1): 193-211.

Smeeding, T., and Gottschalk, P. 1998. "The International Evidence on Income Distribution in Modern Economies: Where Do We Stand?" In: M. Bruno and Y. Mundlab, editors. Contemporary Economic Development Reviewed. London, United Kingdom: Macmillan.

Székely, M. 1998. The Economics of Poverty, Inequality and Wealth Accumulation in Mexico. London, United Kingdom: Macmillan.

Székely, M. and Hilgert, M. 1999. "What's Behind the Inequality We Measure?: An Investigation Using Latin American Data." Research Department Working Paper Series No. 409. Washington, DC, United States: Inter-American Development Bank, Research Department.

Wodon, Q.T., et al. 1999. "Poverty and Policy in Latin America and the Caribbean." Washington, DC, United States: World Bank. Mimeographed document. 


\section{Figure 1}

Inequality in LAC in the 1990s

(Countries with increasing inequality)

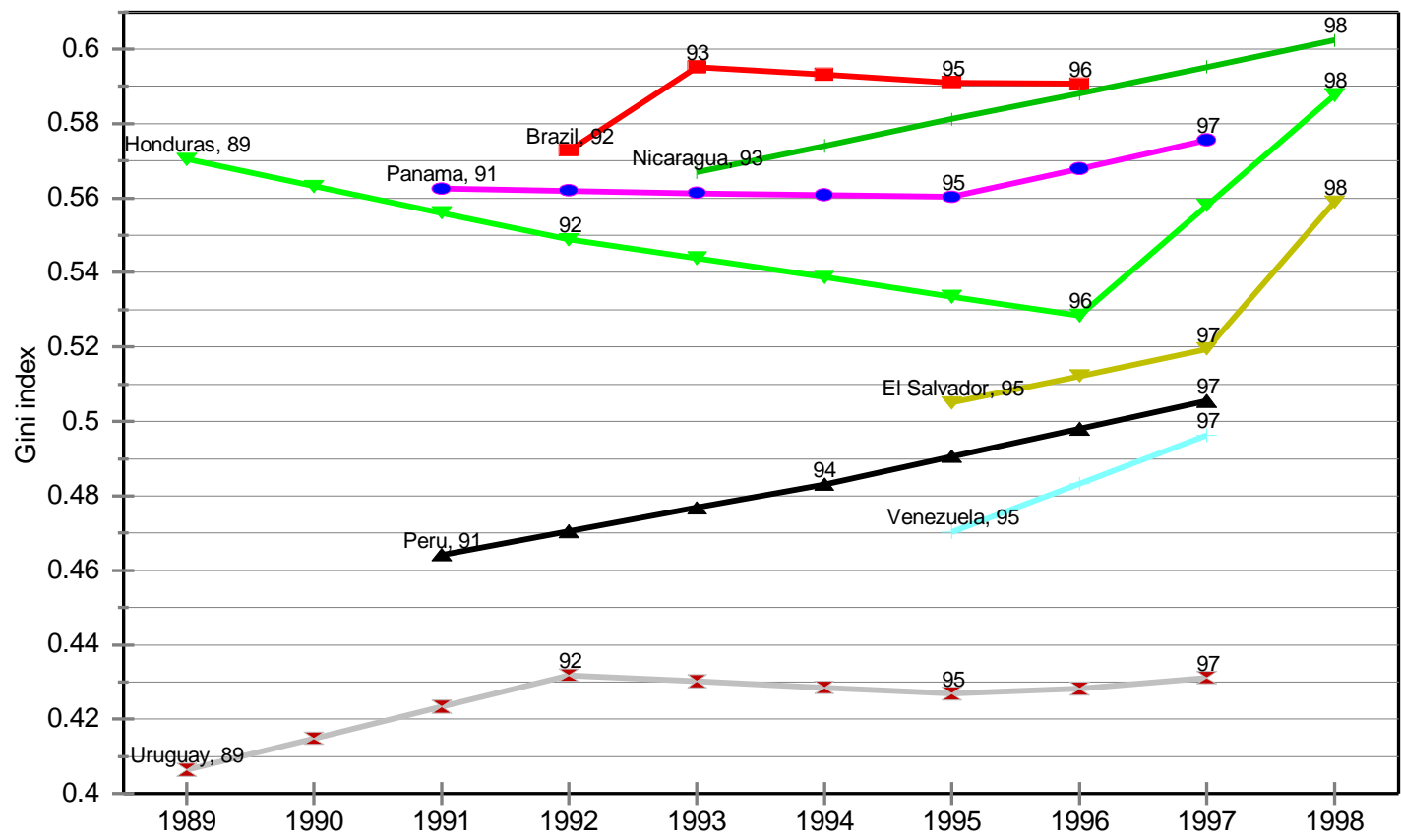

Figure 2

Inequality in LAC in the 1990s

(Countries with constant inequality)

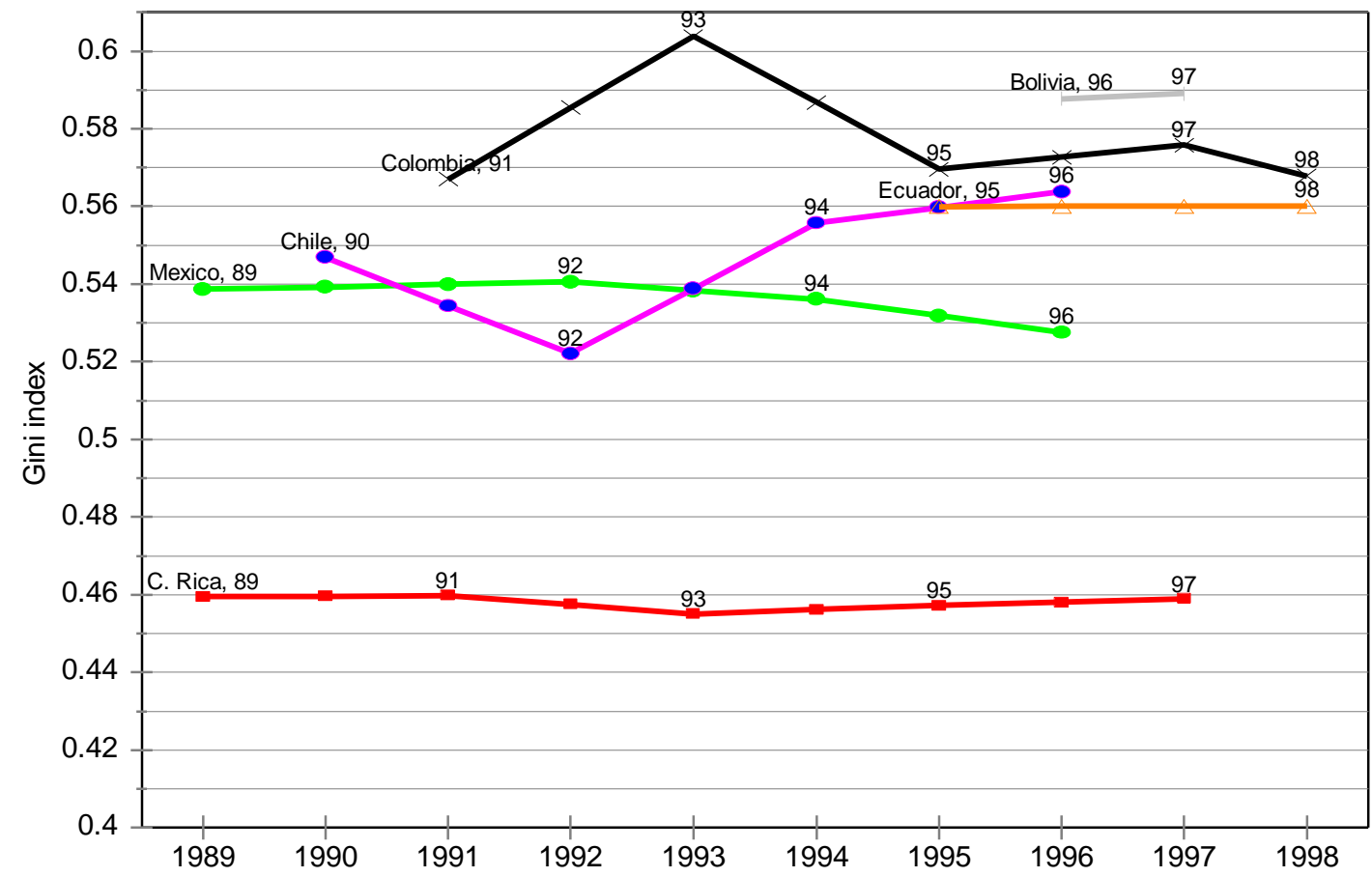


Figure 3

Inequality in Paraguay in the 1990s

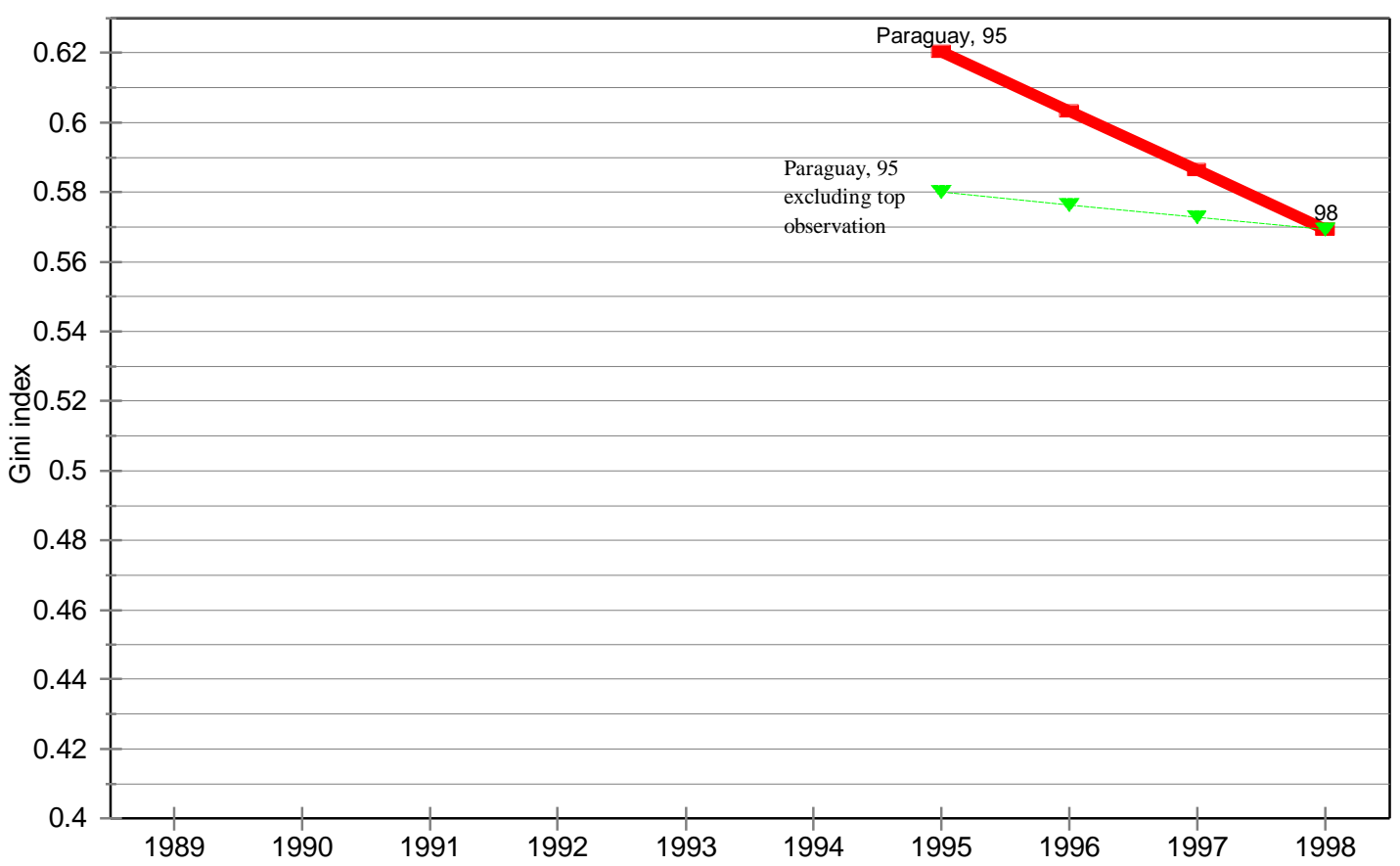

Figure 4

Paraguay, 1995

Paraguay, 1998
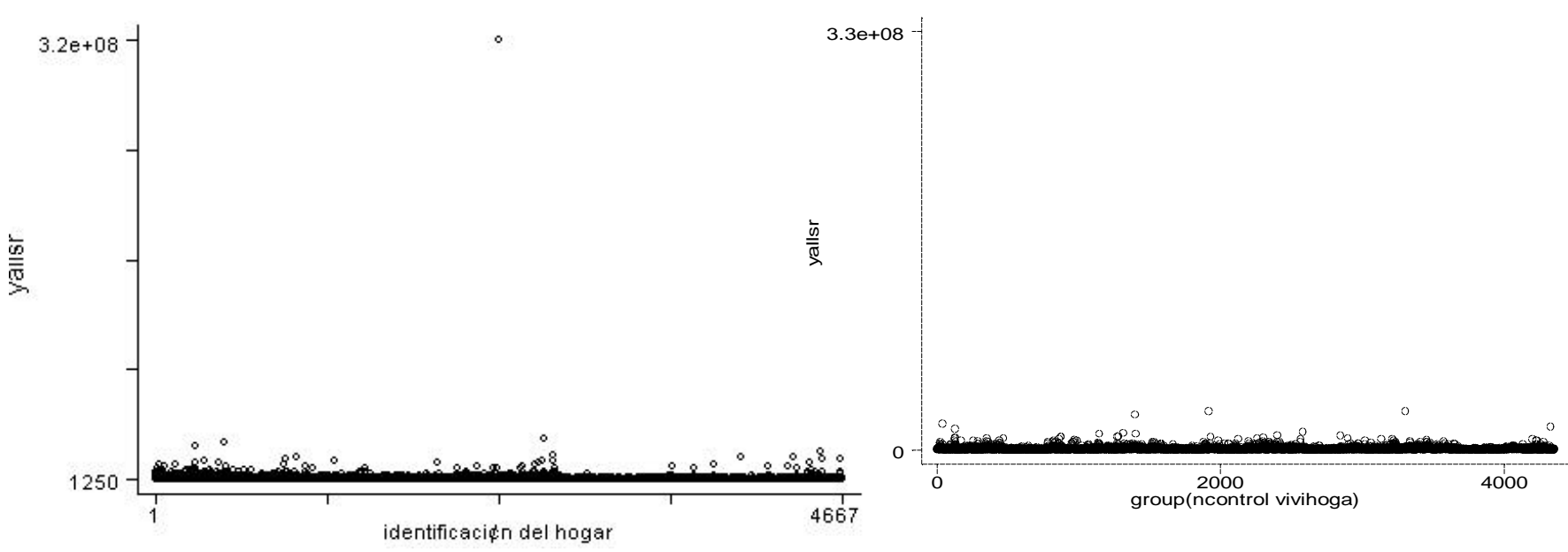


\section{Table 1}

Changes in Income Inequality Around the World in the 1990s

\begin{tabular}{|c|c|c|c|c|c|c|}
\hline Country & Years & $\begin{array}{c}\text { Gini } \\
\text { Year 1 }\end{array}$ & $\begin{array}{c}\text { Gini } \\
\text { Year } 2\end{array}$ & $\begin{array}{c}\text { Change } \\
\text { (Gini Points) }\end{array}$ & $\begin{array}{c}\text { Yearly Chg } \\
\text { (Gini Points) }\end{array}$ & $\begin{array}{c}\text { Yearly Chg } \\
(\%)\end{array}$ \\
\hline Bolivia & $(1996,1997)$ & 0.5877 & 0.5890 & 0.001 & 0.001 & 0.230 \\
\hline Brazil & $(1992,1996)$ & 0.5728 & 0.5906 & 0.018 & 0.018 & 3.114 \\
\hline Chile & $(1990,1996)$ & 0.5470 & 0.5638 & 0.017 & 0.002 & 0.439 \\
\hline Colombia & $(1991,1998)$ & 0.5670 & 0.5679 & 0.001 & 0.000 & 0.022 \\
\hline Costa Rica & $(1989,1997)$ & 0.4595 & 0.4589 & -0.001 & -0.000 & -0.015 \\
\hline Ecuador & $(1995,1998)$ & 0.5600 & 0.5601 & 0.000 & 0.000 & 0.009 \\
\hline El Salvador & $(1995,1998)$ & 0.5050 & 0.5589 & 0.054 & 0.018 & 3.559 \\
\hline Honduras & $(1989,1998)$ & 0.5704 & 0.5876 & 0.017 & 0.003 & 0.504 \\
\hline Mexico & $(1989,1996)$ & 0.5309 & 0.5276 & -0.003 & -0.000 & -0.088 \\
\hline Nicaragua & $(1993,1998)$ & 0.5669 & 0.6024 & 0.035 & 0.007 & 1.252 \\
\hline Panama & $(1991,1997)$ & 0.5625 & 0.5755 & 0.013 & 0.002 & 0.385 \\
\hline Paraguay & $(1995,1998)$ & 0.6203 & 0.5692 & -0.051 & -0.017 & -2.746 \\
\hline Peru & $(1991,1997)$ & 0.4643 & 0.5055 & 0.041 & 0.007 & 1.479 \\
\hline Uruguay & $(1989,1997)$ & 0.4064 & 0.4300 & 0.024 & 0.004 & 0.967 \\
\hline Venezuela & $(1995,1997)$ & 0.4703 & 0.4963 & 0.026 & 0.013 & 2.761 \\
\hline Avg. Latin America & & & & 0.013 & 0.004 & 0.792 \\
\hline Canada & $(1991,1994)$ & 0.3501 & 0.3544 & 0.004 & 0.001 & 0.411 \\
\hline USA & $(1991,1994)$ & 0.4157 & 0.4404 & 0.025 & 0.008 & 1.987 \\
\hline Avg. N. America & & & & 0.015 & 0.005 & 1.199 \\
\hline Australia & $(1989,1994)$ & 0.3809 & 0.3915 & 0.011 & 0.002 & 0.558 \\
\hline Finland & $(1991,1995)$ & 0.2742 & 0.2918 & 0.018 & 0.004 & 1.606 \\
\hline France & $(1989,1994)$ & 0.3395 & 0.3427 & 0.003 & 0.001 & 0.188 \\
\hline Germany & $(1989,1994)$ & 0.3266 & 0.3464 & 0.020 & 0.004 & 1.213 \\
\hline Italy & $(1991,1995)$ & 0.3107 & 0.3621 & 0.051 & 0.013 & 4.136 \\
\hline Luxembourg & $(1991,1994)$ & 0.2694 & 0.2694 & -0.000 & -0.000 & -0.005 \\
\hline Neatherlands & $(1991,1994)$ & 0.3256 & 0.3366 & 0.011 & 0.004 & 1.119 \\
\hline Norway & $(1991,1995)$ & 0.2883 & 0.2935 & 0.005 & 0.001 & 0.450 \\
\hline Sweden & $(1992,1995)$ & 0.2839 & 0.2885 & 0.005 & 0.002 & 0.538 \\
\hline United Kingdom & $(1991,1995)$ & 0.3898 & 0.3966 & 0.007 & 0.002 & 0.439 \\
\hline Avg. Western Europe & & & & 0.015 & 0.004 & 1.158 \\
\hline Hungary & $(1991,1994)$ & 0.2874 & 0.3320 & 0.045 & 0.015 & 5.178 \\
\hline Poland & $(1992,1995)$ & 0.3250 & 0.3749 & 0.050 & 0.017 & 5.122 \\
\hline Russia & $(1992,1995)$ & 0.4404 & 0.4525 & 0.012 & 0.004 & 0.915 \\
\hline Avg. Eastern Europe & & & & 0.036 & 0.012 & 3.738 \\
\hline Thailand & $(1992,1996)$ & 0.5589 & 0.5129 & -0.046 & -0.011 & -2.058 \\
\hline Taiwan & $(1991,1995)$ & 0.3049 & 0.3027 & -0.002 & -0.001 & -0.180 \\
\hline Avg. Eastern Europe & & & & -0.024 & -0.006 & -1.119 \\
\hline
\end{tabular}

Source: Authors' calculations from household survey data. The results for Latin American countries were obtained with direct access to household surveys detailed in the Appendix. The results for Thailand were obtained by processing the Socio-Economic Survey. Household surveys for the rest of the countries wree accessed through the Luxembourg Income Study. 
Table 2

Inequality with Differences in Coverage

\begin{tabular}{|c|c|c|c|c|c|c|c|}
\hline \multirow[t]{2}{*}{ Country } & \multirow[t]{2}{*}{ Year } & \multirow{2}{*}{$\begin{array}{c}\text { Conventional } \\
\text { Gini }\end{array}$} & \multirow{2}{*}{$\begin{array}{l}\text { Gini Labor } \\
\text { Incomes }\end{array}$} & \multicolumn{2}{|c|}{ Gini Index } & \multirow{2}{*}{$\begin{array}{c}\text { Urb/Rur } \\
\text { Ratio }\end{array}$} & \multirow{2}{*}{$\begin{array}{l}\text { \% Urban } \\
\text { Population }\end{array}$} \\
\hline & & & & Urban & Rural & & \\
\hline Bolivia & 1996 & 0.5877 & 0.5805 & 0.5177 & 0.6134 & 3.50 & 0.60 \\
\hline Bolivia & 1997 & 0.5890 & 0.5866 & 0.5292 & 0.6745 & 3.04 & 0.63 \\
\hline Brazil & 1992 & 0.5728 & 0.5809 & 0.5512 & 0.5380 & 2.83 & 0.78 \\
\hline Brazil & 1993 & 0.5952 & 0.6064 & 0.5755 & 0.5780 & 2.62 & 0.78 \\
\hline Brazil & 1995 & 0.5911 & 0.5991 & 0.5695 & 0.5364 & 3.00 & 0.79 \\
\hline Brazil & 1996 & 0.5906 & 0.5965 & 0.5691 & 0.5470 & 2.97 & 0.79 \\
\hline Chile & 1990 & 0.5470 & 0.5587 & 0.5370 & 0.5742 & 1.34 & 0.81 \\
\hline Chile & 1992 & 0.5220 & 0.5428 & 0.5161 & 0.4719 & 1.84 & 0.81 \\
\hline Chile & 1994 & 0.5558 & 0.5767 & 0.5499 & 0.5097 & 1.92 & 0.83 \\
\hline Chile & 1996 & 0.5638 & 0.5845 & 0.5546 & 0.5006 & 2.30 & 0.84 \\
\hline Colombia & 1991 & 0.5670 & 0.5694 & 0.5043 & 0.6210 & 1.93 & 0.58 \\
\hline Colombia & 1993 & 0.6038 & 0.6088 & 0.5634 & 0.5580 & 2.76 & 0.58 \\
\hline Colombia & 1995 & 0.5697 & 0.5808 & 0.5342 & 0.6080 & 0.93 & 0.60 \\
\hline Colombia & 1997 & 0.5758 & 0.5783 & 0.5423 & 0.5022 & 3.04 & 0.61 \\
\hline Colombia & 1998 & 0.5679 & 0.5880 & 0.5295 & 0.5660 & 2.18 & 0.61 \\
\hline Costa Rica & 1989 & 0.4595 & 0.4526 & 0.4431 & 0.4256 & 1.77 & 0.44 \\
\hline Costa Rica & 1991 & 0.4598 & 0.4605 & 0.4332 & 0.4449 & 1.58 & 0.44 \\
\hline Costa Rica & 1993 & 0.4550 & 0.4509 & 0.4336 & 0.4333 & 1.65 & 0.44 \\
\hline Costa Rica & 1995 & 0.4571 & 0.4582 & 0.4292 & 0.4374 & 1.72 & 0.44 \\
\hline Costa Rica & 1997 & 0.4589 & 0.4581 & 0.4367 & 0.4270 & 1.71 & 0.43 \\
\hline Ecuador & 1995 & 0.5600 & 0.5672 & 0.5285 & 0.4890 & 2.75 & 0.59 \\
\hline Ecuador & 1998 & 0.5601 & 0.5627 & 0.5188 & 0.5376 & 2.53 & 0.58 \\
\hline El Salvador & 1995 & 0.5050 & 0.5120 & 0.4639 & 0.4283 & 2.62 & 0.55 \\
\hline El Salvador & 1997 & 0.5195 & 0.5195 & 0.4797 & 0.4454 & 2.97 & 0.55 \\
\hline El Salvador & 1998 & 0.5589 & 0.5432 & 0.4905 & 0.5413 & 2.87 & 0.58 \\
\hline Honduras & 1989 & 0.5704 & 0.5715 & 0.5269 & 0.4984 & 2.91 & 0.33 \\
\hline Honduras & 1992 & 0.5489 & 0.5489 & 0.5153 & 0.4956 & 2.36 & 0.42 \\
\hline Honduras & 1996 & 0.5284 & 0.5302 & 0.4917 & 0.4817 & 2.29 & 0.44 \\
\hline Honduras & 1998 & 0.5876 & 0.5947 & 0.5356 & 0.6065 & 2.22 & 0.44 \\
\hline Mexico & 1989 & 0.5309 & 0.5408 & 0.5201 & 0.4576 & 2.46 & 0.62 \\
\hline Mexico & 1992 & 0.5341 & 0.5671 & 0.5021 & 0.4535 & 2.83 & 0.59 \\
\hline Mexico & 1994 & 0.5361 & 0.5669 & 0.5018 & 0.4403 & 2.83 & 0.58 \\
\hline Mexico & 1996 & 0.5276 & 0.5800 & 0.4892 & 0.4560 & 3.02 & 0.59 \\
\hline Nicaragua & 1993 & 0.5669 & 0.5669 & 0.5305 & 0.5441 & 3.03 & 0.56 \\
\hline Nicaragua & 1998 & 0.6024 & 0.6027 & 0.5779 & 0.5605 & 2.79 & 0.54 \\
\hline Panama & 1991 & 0.5625 & 0.5355 & 0.5127 & 0.5512 & 2.74 & 0.53 \\
\hline Panama & 1995 & 0.5602 & 0.5466 & 0.5147 & 0.5321 & 3.14 & 0.59 \\
\hline Panama & 1997 & 0.5755 & 0.5678 & 0.5287 & 0.5507 & 2.75 & 0.60 \\
\hline Paraguay & 1995 & 0.6203 & 0.6267 & 0.5726 & 0.5664 & 3.09 & 0.51 \\
\hline Paraguay & 1998 & 0.5692 & 0.5662 & 0.5103 & 0.5458 & 3.48 & 0.54 \\
\hline Peru & 1991 & 0.4643 & 0.4917 & 0.4294 & 0.4139 & 2.81 & 0.77 \\
\hline Peru & 1994 & 0.4832 & 0.5003 & 0.4487 & 0.4478 & 2.45 & 0.70 \\
\hline Peru & 1997 & 0.5055 & 0.5301 & 0.4484 & 0.4330 & 3.15 & 0.65 \\
\hline Uruguay & 1989 & 0.4064 & 0.4461 & 0.4064 & & & \\
\hline Uruguay & 1992 & 0.4319 & 0.4562 & 0.4319 & & & \\
\hline Uruguay & 1995 & 0.4209 & 0.4683 & 0.4209 & & & \\
\hline Uruguay & 1997 & 0.4300 & 0.4792 & 0.4300 & & & \\
\hline Venezuela & 1995 & 0.4703 & 0.4664 & 0.4634 & 0.4346 & 1.71 & 0.82 \\
\hline Venezuela & 1997 & 0.4963 & 0.4951 & 0.4963 & & & \\
\hline
\end{tabular}

Source: Authors'calculations from household survey data. 
Table 3

Robustness Tests to Methodological Preferences

\begin{tabular}{|c|c|c|c|c|c|c|c|c|}
\hline \multirow{3}{*}{ Country } & \multirow{3}{*}{ Year } & \multirow{3}{*}{$\begin{array}{l}\text { Economies } \\
\text { of scale } \\
\text { in consump. }\end{array}$} & \multirow{3}{*}{$\begin{array}{c}\text { Adult } \\
\text { equivalence } \\
\text { scale }\end{array}$} & \multirow{2}{*}{\multicolumn{2}{|c|}{ Missing and Zero values }} & \multirow{2}{*}{\multicolumn{2}{|c|}{$\begin{array}{c}\text { Entropy inequality } \\
\text { Measures }\end{array}$}} & \multirow{3}{*}{$\begin{array}{c}\text { Dominance } \\
\text { Tests* } \\
\end{array}$} \\
\hline & & & & & & & & \\
\hline & & & & $\begin{array}{l}(\%) \text { of } \\
\text { all obs. }\end{array}$ & $\begin{array}{l}\text { Gini with } \\
\text { imputation }\end{array}$ & $a=-1$ & $a=+1$ & \\
\hline$\overline{\text { Bolivia }}$ & 1996 & 0.5682 & 0.5670 & 8.0 & 0.5987 & 3.433 & 0.688 & \\
\hline Bolivia & 1997 & 0.5699 & 0.5686 & 11.2 & 0.6242 & 3.655 & 0.699 & -- \\
\hline Brazil & 1992 & 0.5655 & 0.5522 & 3.9 & 0.5809 & 2.640 & 0.653 & \\
\hline Brazil & 1993 & 0.5882 & 0.5759 & 4.0 & 0.6073 & 2.175 & 0.726 & \\
\hline Brazil & 1995 & 0.5840 & 0.5700 & 3.3 & 0.6015 & 1.363 & 0.692 & \\
\hline Brazil & 1996 & 0.5839 & 0.5712 & 4.3 & 0.6005 & 1.342 & 0.685 & -- \\
\hline Chile & 1990 & 0.5423 & 0.5329 & 0.4 & 0.5470 & 0.998 & 0.608 & \\
\hline Chile & 1992 & 0.5169 & 0.5043 & 5.2 & 0.6310 & 0.810 & 0.559 & \\
\hline Chile & 1994 & 0.5504 & 0.5397 & 0.6 & 0.5560 & 0.890 & 0.597 & \\
\hline Chile & 1996 & 0.5578 & 0.5358 & 0.2 & 0.5637 & 1.045 & 0.656 & -- \\
\hline Colombia & 1991 & 0.5425 & 0.5460 & 4.6 & 0.5654 & 1.241 & 0.837 & \\
\hline Colombia & 1993 & 0.5791 & 0.5854 & 1.0 & 0.6033 & 1.394 & 0.989 & \\
\hline Colombia & 1995 & 0.5489 & 0.5535 & 5.6 & 0.5826 & 1.058 & 0.686 & \\
\hline Colombia & 1997 & 0.5479 & 0.5540 & 1.5 & 0.5757 & 1.556 & 0.854 & \\
\hline Colombia & 1998 & 0.5437 & 0.5425 & 2.3 & 0.5774 & 2.638 & 0.721 & 1991 \\
\hline Costa Rica & 1989 & 0.4519 & 0.4391 & 13.6 & 0.4599 & 0.766 & 0.384 & \\
\hline Costa Rica & 1991 & 0.4532 & 0.4361 & 25.8 & 0.4632 & 0.706 & 0.389 & \\
\hline Costa Rica & 1993 & 0.4479 & 0.4338 & 24.7 & 0.4569 & 0.745 & 0.376 & \\
\hline Costa Rica & 1995 & 0.4499 & 0.4366 & 18.6 & 0.4646 & 0.713 & 0.380 & \\
\hline Costa Rica & 1997 & 0.4332 & 0.4352 & 16.8 & 0.4617 & 0.628 & 0.381 & -- \\
\hline Ecuador & 1995 & 0.5269 & 0.5401 & 1.9 & 0.5600 & 1.792 & 0.164 & \\
\hline Ecuador & 1998 & 0.5305 & 0.5497 & 4.0 & 0.5750 & 1.940 & 0.494 & 1995 \\
\hline El Salvador & 1995 & 0.4732 & 0.4800 & 0.7 & 0.5219 & 0.963 & 0.309 & \\
\hline El Salvador & 1997 & 0.4867 & 0.4983 & 16.5 & 0.5817 & 0.705 & 0.457 & \\
\hline El Salvadoı & 1998 & 0.5362 & 0.5425 & 7.9 & 0.5587 & 2.540 & 0.523 & 1995 \\
\hline Honduras & 1989 & 0.5401 & 0.5453 & 9.8 & 0.5691 & 1.018 & 0.647 & \\
\hline Honduras & 1992 & 0.5407 & 0.5252 & 9.0 & 0.5688 & 1.113 & 0.586 & \\
\hline Honduras & 1996 & 0.5203 & 0.5056 & 9.1 & 0.5482 & 0.831 & 0.565 & \\
\hline Honduras & 1998 & 0.5825 & 0.5698 & 7.4 & 0.5932 & 2.539 & 0.669 & 1992 \\
\hline Mexico & 1989 & 0.5280 & 0.5016 & 0.1 & 0.5309 & 0.806 & 0.525 & \\
\hline Mexico & 1992 & 0.5310 & 0.5116 & 0.0 & 0.5341 & 0.768 & 0.573 & \\
\hline Mexico & 1994 & 0.5258 & 0.5088 & 0.0 & 0.5361 & 0.756 & 0.573 & \\
\hline Mexico & 1996 & 0.5300 & 0.4916 & 0.0 & 0.5300 & 0.750 & 0.590 & -- \\
\hline Nicaragua & 1993 & 0.5385 & 0.5464 & 22.6 & 0.6537 & 2.286 & 0.643 & \\
\hline Nicaragua & 1998 & 0.5742 & 0.5684 & 14.4 & 0.6503 & 2.567 & 0.683 & 1993 \\
\hline Panama & 1991 & 0.5547 & 0.5438 & 6.5 & 0.5882 & 2.098 & 0.591 & \\
\hline Panama & 1995 & 0.5523 & 0.5387 & 6.3 & 0.5857 & 1.968 & 0.590 & \\
\hline Panama & 1997 & 0.5686 & 0.5543 & 7.1 & 0.5832 & 1.820 & 0.640 & -- \\
\hline Paraguay & 1995 & 0.5876 & 0.5936 & 1.9 & 0.6200 & 1.634 & 1.015 & 1998 \\
\hline Paraguay & 1998 & 0.5450 & 0.5482 & 7.2 & 0.6135 & 3.687 & 0.978 & \\
\hline Peru & 1991 & 0.4568 & 0.4411 & 0.0 & 0.4643 & 0.606 & 0.408 & \\
\hline Peru & 1994 & 0.4747 & 0.4540 & 0.0 & 0.4832 & 0.712 & 0.452 & \\
\hline Peru & 1997 & 0.4983 & 0.4791 & 0.1 & 0.5055 & 0.799 & 0.500 & 1991 \\
\hline Uruguay & 1989 & 0.3979 & 0.3843 & 0.0 & 0.4064 & 0.375 & 0.251 & \\
\hline Uruguay & 1992 & 0.4227 & 0.4085 & 0.0 & 0.4319 & 0.477 & 0.282 & \\
\hline Uruguay & 1995 & 0.4116 & 0.3966 & 0.0 & 0.4209 & 0.444 & 0.267 & \\
\hline Uruguay & 1997 & 0.3906 & 0.4010 & 0.0 & 0.4300 & 0.454 & 0.285 & 1989 \\
\hline Venezuela & 1995 & 0.4613 & 0.4425 & 11.6 & 0.4676 & 1.355 & 0.404 & \\
\hline Venezuela & 1997 & 0.4873 & 0.4722 & 23.3 & 0.5312 & 1.470 & 0.468 & 1995 \\
\hline
\end{tabular}


Table 4

Inequality with Truncated Income Distributic

\begin{tabular}{|c|c|c|c|c|c|c|}
\hline \multirow[t]{3}{*}{ Country } & \multirow[t]{3}{*}{ Year } & \multicolumn{5}{|c|}{ Excluding } \\
\hline & & Richest & Richest & Richest & Richest & Richest \\
\hline & & 10 hhs & $1 \%$ & $2 \%$ & $5 \%$ & $10 \%$ \\
\hline Bolivia & 1996 & 0.5737 & 0.5384 & 0.5193 & 0.4837 & 0.4466 \\
\hline Bolivia & 1997 & 0.5786 & 0.5370 & 0.5158 & 0.4791 & 0.4438 \\
\hline Brazil & 1992 & 0.5694 & 0.5262 & 0.5049 & 0.4634 & 0.4216 \\
\hline Brazil & 1993 & 0.5921 & 0.5424 & 0.5188 & 0.4736 & 0.4276 \\
\hline Brazil & 1995 & 0.5901 & 0.5447 & 0.5222 & 0.4781 & 0.4317 \\
\hline Brazil & 1996 & 0.5891 & 0.5460 & 0.5240 & 0.4814 & 0.4375 \\
\hline Chile & 1990 & 0.5429 & 0.4958 & 0.4738 & 0.4290 & 0.3793 \\
\hline Chile & 1992 & 0.5199 & 0.4719 & 0.4471 & 0.4010 & 0.3581 \\
\hline Chile & 1994 & 0.5383 & 0.4906 & 0.4675 & 0.4250 & 0.3802 \\
\hline Chile & 1996 & 0.5575 & 0.5110 & 0.4839 & 0.4347 & 0.3871 \\
\hline Colombia & 1991 & 0.5498 & 0.4630 & 0.4417 & 0.4037 & 0.3671 \\
\hline Colombia & 1993 & 0.5889 & 0.4874 & 0.4654 & 0.4265 & 0.3880 \\
\hline Colombia & 1995 & 0.5664 & 0.5070 & 0.4848 & 0.4421 & 0.3966 \\
\hline Colombia & 1997 & 0.5512 & 0.5060 & 0.4851 & 0.4446 & 0.4034 \\
\hline Colombia & 1998 & 0.5544 & 0.5094 & 0.4850 & 0.4377 & 0.3920 \\
\hline Costa Rica & 1989 & 0.4516 & 0.4287 & 0.4140 & 0.3866 & 0.3568 \\
\hline Costa Rica & 1991 & 0.4497 & 0.4263 & 0.4126 & 0.3843 & 0.3538 \\
\hline Costa Rica & 1993 & 0.4476 & 0.4251 & 0.4105 & 0.3802 & 0.3493 \\
\hline Costa Rica & 1995 & 0.4517 & 0.4241 & 0.4079 & 0.3789 & 0.3488 \\
\hline Costa Rica & 1997 & 0.4553 & 0.4273 & 0.4119 & 0.3822 & 0.3510 \\
\hline Ecuador & 1995 & 0.5379 & 0.5015 & 0.4803 & 0.4387 & 0.3983 \\
\hline Ecuador & 1998 & 0.5471 & 0.5130 & 0.4917 & 0.4510 & 0.4124 \\
\hline El Salvador & 1995 & 0.4938 & 0.4582 & 0.4364 & 0.3998 & 0.3655 \\
\hline El Salvador & 1997 & 0.5078 & 0.4718 & 0.4524 & 0.4180 & 0.3830 \\
\hline El Salvador & 1998 & 0.5480 & 0.5186 & 0.5017 & 0.4691 & 0.4385 \\
\hline Honduras & 1989 & 0.5635 & 0.5227 & 0.4993 & 0.4544 & 0.4092 \\
\hline Honduras & 1992 & 0.5435 & 0.5024 & 0.4809 & 0.4432 & 0.4062 \\
\hline Honduras & 1996 & 0.5175 & 0.4760 & 0.4557 & 0.4218 & 0.3868 \\
\hline Honduras & 1998 & 0.5818 & 0.5435 & 0.5235 & 0.4893 & 0.4566 \\
\hline Mexico & 1989 & 0.5236 & 0.4735 & 0.4494 & 0.4078 & 0.3671 \\
\hline Mexico & 1992 & 0.5200 & 0.4892 & 0.4664 & 0.4241 & 0.3800 \\
\hline Mexico & 1994 & 0.5295 & 0.4887 & 0.4646 & 0.4189 & 0.3740 \\
\hline Mexico & 1996 & 0.5286 & 0.4600 & 0.4200 & 0.3900 & 0.3400 \\
\hline Nicaragua & 1993 & 0.5521 & 0.5147 & 0.4938 & 0.4551 & 0.4229 \\
\hline Nicaragua & 1998 & 0.5579 & 0.5308 & 0.5059 & 0.4634 & 0.4254 \\
\hline Panama & 1991 & 0.5556 & 0.5275 & 0.5098 & 0.4785 & 0.4454 \\
\hline Panama & 1995 & 0.5555 & 0.5237 & 0.5046 & 0.4667 & 0.4302 \\
\hline Panama & 1997 & 0.5698 & 0.5315 & 0.5112 & 0.4744 & 0.4389 \\
\hline Paraguay & 1995 & 0.5736 & 0.5361 & 0.5119 & 0.4702 & 0.4288 \\
\hline Paraguay & 1998 & 0.5559 & 0.5379 & 0.5244 & 0.4923 & 0.4567 \\
\hline Peru & 1991 & 0.4479 & 0.4248 & 0.4095 & 0.3800 & 0.3509 \\
\hline Peru & 1994 & 0.4695 & 0.4385 & 0.4215 & 0.3918 & 0.3620 \\
\hline Peru & 1997 & 0.4938 & 0.4589 & 0.4375 & 0.4003 & 0.3684 \\
\hline Uruguay & 1989 & 0.3934 & 0.3696 & 0.3570 & 0.3316 & 0.3046 \\
\hline Uruguay & 1992 & 0.4263 & 0.4010 & 0.3859 & 0.3564 & 0.3270 \\
\hline Uruguay & 1995 & 0.4189 & 0.3942 & 0.3810 & 0.3540 & 0.3250 \\
\hline Uruguay & 1997 & 0.4246 & 0.3989 & 0.3846 & 0.3561 & 0.3252 \\
\hline Venezuela & 1995 & 0.4673 & 0.4317 & 0.4150 & 0.3841 & 0.3529 \\
\hline Venezuela & 1997 & 0.4897 & 0.4560 & 0.4386 & 0.4051 & 0.3706 \\
\hline
\end{tabular}

Source: Authors'calculations from household survey data. 
Table 5

Inequality by Excluding Education Groups

\begin{tabular}{|c|c|c|c|c|c|}
\hline \multirow[t]{2}{*}{ Country } & \multirow[t]{2}{*}{ Year } & \multicolumn{4}{|c|}{ Excluding } \\
\hline & & $\begin{array}{l}\text { Years of } \\
\text { educ }>19\end{array}$ & $\begin{array}{l}\text { Years of } \\
\text { educ }>17\end{array}$ & $\begin{array}{l}\text { Years of } \\
\text { educ }>14\end{array}$ & $\begin{array}{l}\text { Years of } \\
\text { educ }>11\end{array}$ \\
\hline Bolivia & 1996 & 0.5882 & 0.5882 & 0.5682 & 0.5599 \\
\hline Bolivia & 1997 & 0.5913 & 0.5913 & 0.5677 & 0.5620 \\
\hline Brazil & 1992 & 0.5702 & 0.5690 & 0.5452 & 0.5377 \\
\hline Brazil & 1993 & 0.5930 & 0.5912 & 0.5648 & 0.5565 \\
\hline Brazil & 1995 & 0.5887 & 0.5868 & 0.5562 & 0.5477 \\
\hline Brazil & 1996 & 0.5884 & 0.5860 & 0.5576 & 0.5506 \\
\hline Chile & 1990 & 0.5472 & 0.5415 & 0.5266 & 0.5268 \\
\hline Chile & 1992 & 0.5220 & 0.5099 & 0.4872 & 0.4852 \\
\hline Chile & 1994 & 0.5566 & 0.5492 & 0.5270 & 0.5075 \\
\hline Chile & 1996 & 0.5634 & 0.5554 & 0.5349 & 0.5296 \\
\hline Colombia & 1991 & 0.5708 & 0.5699 & 0.5497 & 0.5468 \\
\hline Colombia & 1993 & 0.6069 & 0.6037 & 0.5717 & 0.5673 \\
\hline Colombia & 1995 & 0.5714 & 0.5703 & 0.5564 & 0.5562 \\
\hline Colombia & 1997 & 0.5793 & 0.5760 & 0.5469 & 0.5426 \\
\hline Colombia & 1998 & 0.5707 & 0.5633 & 0.5317 & 0.5235 \\
\hline Costa Rica & 1989 & 0.4590 & 0.4573 & 0.4445 & 0.4383 \\
\hline Costa Rica & 1991 & 0.4614 & 0.4571 & 0.4464 & 0.4379 \\
\hline Costa Rica & 1993 & 0.4542 & 0.4507 & 0.4372 & 0.4318 \\
\hline Costa Rica & 1995 & 0.4569 & 0.4542 & 0.4370 & 0.4286 \\
\hline Costa Rica & 1997 & 0.4590 & 0.4567 & 0.4381 & 0.4289 \\
\hline Ecuador & 1995 & 0.5629 & 0.5560 & 0.5431 & 0.5316 \\
\hline Ecuador & 1998 & 0.5606 & 0.5492 & 0.5367 & 0.5199 \\
\hline El Salvador & 1995 & 0.5044 & 0.5039 & 0.4828 & 0.4631 \\
\hline El Salvador & 1997 & 0.5202 & 0.5191 & 0.4952 & 0.4841 \\
\hline El Salvador & 1998 & 0.5578 & 0.5572 & 0.5462 & 0.5367 \\
\hline Honduras & 1989 & 0.5723 & 0.5645 & 0.5513 & 0.5296 \\
\hline Honduras & 1992 & 0.5507 & 0.5437 & 0.5323 & 0.5114 \\
\hline Honduras & 1996 & 0.5295 & 0.5243 & 0.5077 & 0.4913 \\
\hline Honduras & 1998 & 0.5865 & 0.5857 & 0.5841 & 0.5869 \\
\hline Mexico & 1989 & 0.5355 & 0.5352 & 0.5126 & 0.5056 \\
\hline Mexico & 1992 & 0.5383 & 0.5383 & 0.5139 & 0.5032 \\
\hline Mexico & 1994 & 0.5328 & 0.5329 & 0.5035 & 0.4871 \\
\hline Mexico & 1996 & 0.5143 & 0.4983 & 0.4881 & 0.4668 \\
\hline Nicaragua & 1993 & 0.5669 & 0.5669 & 0.5598 & 0.5584 \\
\hline Nicaragua & 1998 & 0.5909 & 0.5909 & 0.5542 & 0.5504 \\
\hline Panama & 1991 & 0.5621 & 0.5558 & 0.5444 & 0.5364 \\
\hline Panama & 1995 & 0.5555 & 0.5474 & 0.5291 & 0.5270 \\
\hline Panama & 1997 & 0.5720 & 0.5544 & 0.5300 & 0.5430 \\
\hline Paraguay & 1995 & 0.6203 & 0.6117 & 0.6080 & 0.6048 \\
\hline Paraguay & 1998 & 0.5383 & 0.5383 & 0.5376 & 0.5376 \\
\hline Peru & 1991 & 0.4584 & 0.4583 & 0.4404 & 0.4368 \\
\hline Peru & 1994 & 0.4806 & 0.4785 & 0.4518 & 0.4439 \\
\hline Peru & 1997 & 0.5025 & 0.5003 & 0.4706 & 0.4633 \\
\hline Uruguay & 1989 & 0.3992 & 0.3992 & 0.3952 & 0.3905 \\
\hline Uruguay & 1992 & 0.4306 & 0.4255 & 0.4161 & 0.4105 \\
\hline Uruguay & 1995 & 0.4196 & 0.4143 & 0.4043 & 0.3969 \\
\hline Uruguay & 1997 & 0.4251 & 0.4207 & 0.4082 & 0.3982 \\
\hline Venezuela & 1995 & 0.4706 & 0.4702 & 0.4537 & 0.4457 \\
\hline Venezuela & 1997 & 0.4863 & 0.4841 & 0.4693 & 0.4644 \\
\hline
\end{tabular}

Source: Authors'calculations from household survey data. 


\section{Table 6}

Decomposition of the Change in Inequality by Income Source

\begin{tabular}{|c|c|c|c|c|c|c|}
\hline \multirow[t]{4}{*}{ Country } & \multirow[t]{4}{*}{ Effect } & \multirow[t]{4}{*}{ Total } & \multicolumn{4}{|c|}{$(\%)$ Contribution by Source } \\
\hline & & & Labor & Labor & Non-Labor & Non- \\
\hline & & & Income & Income & Income & Monetary \\
\hline & & & Employees & Self-emp & & Income \\
\hline \multirow[t]{3}{*}{ Brazil } & Factor share effect & 5.5 & 23.2 & -16.5 & -1.3 & \\
\hline & Inequality Effect & 94.5 & 95.1 & -43.4 & 42.9 & \\
\hline & Total & 100 & 118.3 & -59.9 & 41.6 & \\
\hline \multirow[t]{3}{*}{ Chile } & Factor share effect & 4.6 & -15.7 & -11.2 & 13.7 & 17.8 \\
\hline & Inequality Effect & 95.4 & 51.6 & -13.1 & 28.3 & 28.6 \\
\hline & Total & 100 & 35.9 & -24.3 & 42.0 & 46.3 \\
\hline \multirow[t]{3}{*}{ Colombia } & Factor share effect & -3.1 & -2.2 & 2.2 & -3.3 & 0.2 \\
\hline & Inequality Effect & 103.1 & 31.5 & 19.2 & 52.3 & 0.0 \\
\hline & Total & 100 & 29.3 & 21.5 & 49.0 & 0.2 \\
\hline \multirow[t]{3}{*}{ Costa Rica } & Factor share effect & 6.6 & 39.0 & -13.1 & -19.3 & \\
\hline & Inequality Effect & 93.4 & 178.2 & -104.3 & 19.5 & \\
\hline & Total & 100 & 217.2 & -117.4 & 0.2 & \\
\hline \multirow[t]{3}{*}{ Ecuador } & Factor share effect & -159.7 & -161.3 & -20.0 & 21.6 & 0.0 \\
\hline & Inequality Effect & 259.7 & 429.6 & -224.1 & 49.7 & 4.6 \\
\hline & Total & 100 & 268.3 & -244.1 & 71.2 & 4.6 \\
\hline \multirow[t]{3}{*}{ El Salvador } & Factor share effect & 18.3 & 20.9 & 12.6 & -15.2 & \\
\hline & Inequality Effect & 81.7 & -3.8 & 95.0 & -9.6 & \\
\hline & Total & 100 & 17.2 & 107.6 & -24.8 & \\
\hline \multirow[t]{3}{*}{ Honduras } & Factor share effect & 32.9 & -77.0 & 115.2 & -5.4 & \\
\hline & Inequality Effect & 67.1 & 131.8 & -59.3 & -5.4 & \\
\hline & Total & 100 & 54.8 & 55.9 & -10.7 & \\
\hline \multirow[t]{3}{*}{ Mexico } & Factor share effect & 0.4 & -0.3 & 4.1 & 0.7 & -4.2 \\
\hline & Inequality Effect & 99.6 & 134.6 & -42.0 & 14.6 & -7.6 \\
\hline & Total & 100 & 134.4 & -37.9 & 15.3 & -11.8 \\
\hline \multirow[t]{3}{*}{ Nicaragua } & Factor share effect & -0.8 & -2.6 & 1.8 & & \\
\hline & Inequality Effect & 100.8 & 8.8 & 92.0 & & \\
\hline & Total & 100 & 6.3 & 93.7 & & \\
\hline \multirow[t]{3}{*}{ Panama } & Factor share effect & 3.7 & 15.0 & -4.4 & -6.9 & \\
\hline & Inequality Effect & 96.3 & 88.2 & -20.8 & 28.9 & \\
\hline & Total & 100 & 103.2 & -25.2 & 22.0 & \\
\hline \multirow[t]{3}{*}{ Paraguay } & Factor share effect & -18.0 & -22.8 & 6.2 & -1.5 & \\
\hline & Inequality Effect & 118.0 & 115.8 & -3.7 & 5.9 & \\
\hline & Total & 100 & 93.0 & 2.5 & 4.4 & \\
\hline \multirow[t]{3}{*}{ Peru } & Factor share effect & 9.9 & -6.4 & -0.8 & 1.3 & 15.9 \\
\hline & Inequality Effect & 90.1 & 11.2 & -13.8 & 2.5 & 90.2 \\
\hline & Total & 100 & 4.7 & -14.6 & 3.8 & 106.1 \\
\hline \multirow[t]{3}{*}{ Uruguay } & Factor share effect & 4.5 & 6.9 & 4.3 & -12.4 & 5.7 \\
\hline & Inequality Effect & 95.5 & 105.0 & -13.6 & 5.2 & -1.1 \\
\hline & Total & 100 & 111.9 & -9.3 & -7.2 & 4.6 \\
\hline \multirow[t]{3}{*}{ Venezuela* } & Factor share effect & 1.3 & 7.0 & -4.3 & -1.4 & \\
\hline & Inequality Effect & -0.3 & -82.1 & 112.5 & -30.7 & \\
\hline & Total & 1 & -75.1 & 108.1 & -32.1 & \\
\hline
\end{tabular}

Source: Authors'calculations from household survey data.

*Results are divided by 100 due to the low value of the denominator. 


\section{Appendix}

\section{Table A.1}

\begin{tabular}{|c|c|c|c|c|c|}
\hline Country & Year & Name of the survey & Coverage & $\begin{array}{l}\text { Month when } \\
\text { Survey was Held }\end{array}$ & $\begin{array}{l}\text { Reference } \\
\text { Month for Incomes }\end{array}$ \\
\hline \multirow[t]{2}{*}{ Bolivia } & 96 & Encuesta Nacional de Empleo & National & June & June \\
\hline & 97 & Encuesta Nacional de Empleo & National & November & November \\
\hline \multirow[t]{4}{*}{ Brazil } & 92 & Pesquisa Nacional por Amostra de Domicilios & National & September & September \\
\hline & 93 & Pesquisa Nacional por Amostra de Domicilios & National & September & September \\
\hline & 95 & Pesquisa Nacional por Amostra de Domicilios & National & September & September \\
\hline & 96 & Pesquisa Nacional por Amostra de Domicilios & National & September & September \\
\hline \multirow[t]{4}{*}{ Chile } & 90 & Encuesta de Caracterización Socioeconómica Nacional & National & November & October \\
\hline & 92 & Encuesta de Caracterización Socioeconómica Nacional & National & November & October \\
\hline & 94 & Encuesta de Caracterización Socioeconómica Nacional & National & November & October \\
\hline & 96 & Encuesta de Caracterización Socioeconómica Nacional & National & November & October \\
\hline \multirow[t]{5}{*}{ Colombia } & 91 & Encuesta Nacional de Hogares - Fuerza de Trabajo & National & December & November \\
\hline & 93 & Encuesta Nacional de Hogares - Fuerza de Trabajo & National & September & August \\
\hline & 95 & Encuesta Nacional de Hogares - Fuerza de Trabajo & National & September & August \\
\hline & 97 & Encuesta Nacional de Hogares - Fuerza de Trabajo & National & September & August \\
\hline & 98 & Encuesta Nacional de Hogares - Fuerza de Trabajo & National & September & August \\
\hline \multirow[t]{5}{*}{ Costa Rica } & 89 & Encuesta de Hogares de Propósitos Múltiples & National & July & July \\
\hline & 91 & Encuesta de Hogares de Propósitos Múltiples & National & July & July \\
\hline & 93 & Encuesta de Hogares de Propósitos Múltiples & National & July & July \\
\hline & 95 & Encuesta de Hogares de Propósitos Múltiples & National & July & July \\
\hline & 97 & Encuesta de Hogares de Propósitos Múltiples & National & July & July \\
\hline \multirow[t]{2}{*}{ Ecuador } & 95 & Encuesta de Condiciones de Vida & National & August to November & Depends, Prim. July-Sept. \\
\hline & 98 & Encuesta de Condiciones de Vida & National & August to November & Depends, Prim. July-Sept. \\
\hline \multirow[t]{3}{*}{ El Salvador } & 95 & Encuesta de Hogares de Propósitos Múltiples & National & 1995 & 1995 \\
\hline & 97 & Encuesta de Hogares de Propósitos Múltiples & National & 1997 & 1997 \\
\hline & 98 & Encuesta de Hogares de Propósitos Múltiples & National & May-Dec. & May-Dec. \\
\hline \multirow[t]{4}{*}{ Honduras } & 89 & Encuesta Permanente de Hogares de Propósitos Múltiples & National & September & August \\
\hline & 92 & Encuesta Permanente de Hogares de Propósitos Múltiples & National & September & August \\
\hline & 96 & Encuesta Permanente de Hogares de Propósitos Múltiples & National & September & August \\
\hline & 98 & Encuesta Permanente de Hogares de Propósitos Múltiples & National & March & February \\
\hline \multirow[t]{4}{*}{ Mexico } & 89 & Encuesta Nacional de Ingreso Gasto de los Hogares & National & Third quarter & Third quarter \\
\hline & 92 & Encuesta Nacional de Ingreso Gasto de los Hogares & National & Third quarter & Third quarter \\
\hline & 94 & Encuesta Nacional de Ingreso Gasto de los Hogares & National & Third quarter & Third quarter \\
\hline & 96 & Encuesta Nacional de Ingreso Gasto de los Hogares & National & Third quarter & Third quarter \\
\hline \multirow[t]{2}{*}{ Nicaragua } & 93 & Encuesta Nacional de Hogares Sobre Medicion de Niveles de Vida & National & February to June & February to June \\
\hline & 98 & Encuesta Nacional de Hogares Sobre Medicion de Niveles de Vida & National & April to September & April to September \\
\hline \multirow[t]{3}{*}{ Panama } & 91 & Encuesta Continua de Hogares - Mano de Obra & National & August & Julio \\
\hline & 95 & Encuesta Continua de Hogares & National & August & Julio \\
\hline & 97 & Encuesta de Hogares & National & August & Julio \\
\hline \multirow[t]{2}{*}{ Paraguay } & 95 & Encuesta de Hogares - Mano de Obra & National & August to November & August to November \\
\hline & 98 & Encuesta Integrada de Hogares & National & Aug. 97 to July 98 & Depends, prim Aug. to Jul. \\
\hline \multirow[t]{3}{*}{ Peru } & 91 & Encuesta Nacional de Hogares sobre Medición de Niveles de Vida & National & September-November & August-October \\
\hline & 94 & Encuesta Nacional de Hogares sobre Medición de Niveles de Vida & National & May-August & April-July \\
\hline & 97 & Encuesta Nacional de Hogares sobre Medición de Niveles de Vida & National & September-November & August-October \\
\hline \multirow[t]{4}{*}{ Uruguay } & 89 & Encuesta Continua de Hogares & Urban & Second semester & Second semester \\
\hline & 92 & Encuesta Continua de Hogares & Urban & Second semester & Second semester \\
\hline & 95 & Encuesta Continua de Hogares & Urban & 1995 & 1995 \\
\hline & 97 & Encuesta Continua de Hogares & Urban & 1997 & 1997 \\
\hline \multirow[t]{2}{*}{ Venezuela } & 95 & Encuesta de Hogares por Muestra & National & Second semester & Second semester \\
\hline & 97 & Encuesta de Hogares por Muestra & National & Second semester & Second semester \\
\hline
\end{tabular}


Table A.2

Description of the Data

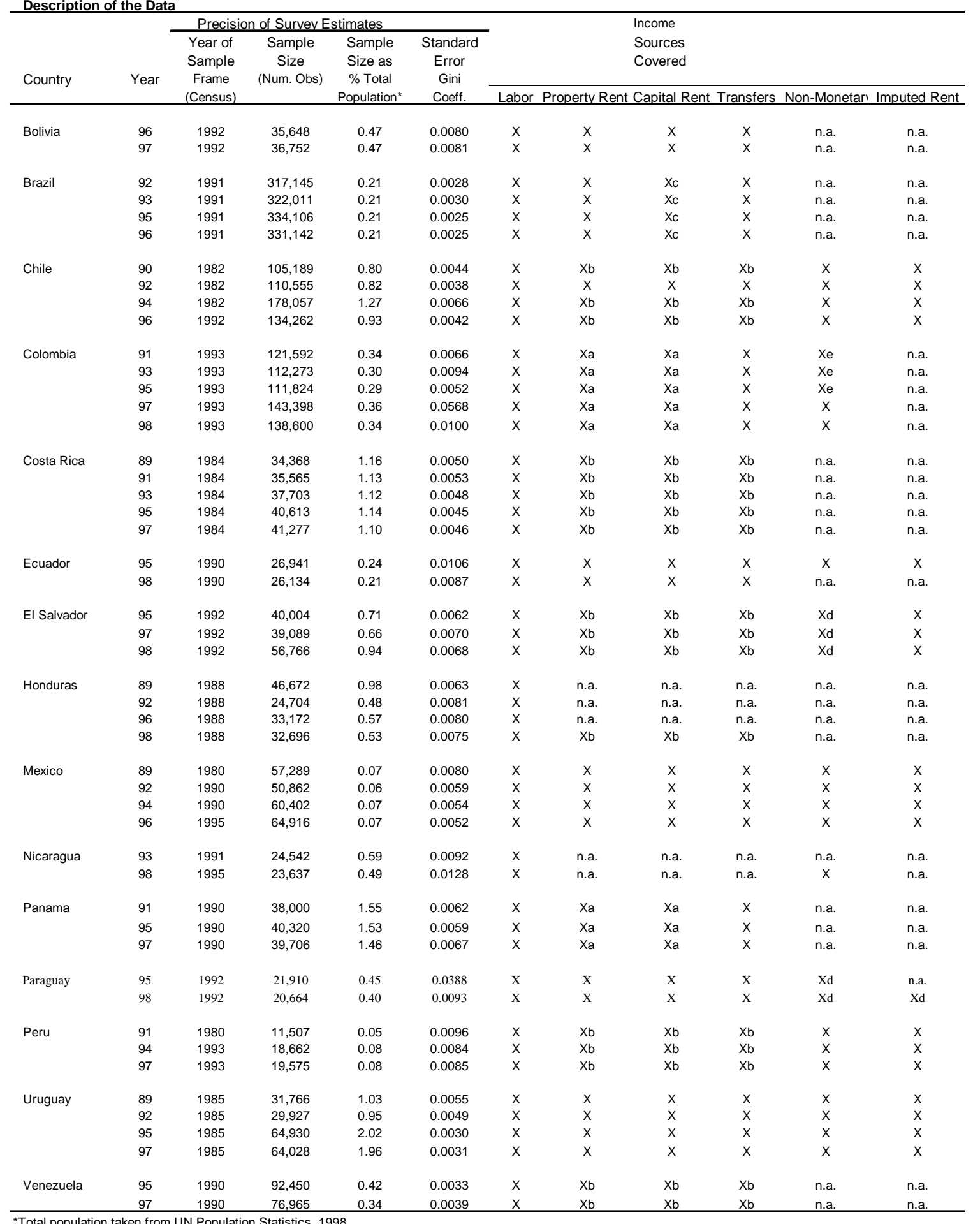

${ }^{\star}$ Total population taken from UN Population Statistics, 1998

a. Can not separate between property and capital rent.

c. Can not separate capital rent from other sources

c. Can not separate capital rent from other sources
d. Can not separate nonmonetary income from labor income. 
Table A.3

Comparison of Income Shares of Different Deciles

\begin{tabular}{|c|c|c|c|c|c|c|}
\hline Country & year & $\begin{array}{l}\text { Top 10\% vs } \\
\text { Bottom } 10 \%\end{array}$ & $\begin{array}{l}\text { Top 10\% vs } \\
\text { Bottom 30\% }\end{array}$ & $\begin{array}{l}\text { Top 20\% vs } \\
\text { Bottom 20\% }\end{array}$ & $\begin{array}{l}\text { Income share } \\
\text { bottom } 10 \%\end{array}$ & $\begin{array}{c}\text { Income } \\
\text { share top } 10 \%\end{array}$ \\
\hline Bolivia & 1996 & 103.3 & 10.7 & 34.1 & 0.004 & 0.453 \\
\hline Bolivia & 1997 & 114.6 & 10.7 & 34.9 & 0.004 & 0.456 \\
\hline Brazil & 1992 & 56.1 & 8.6 & 23.8 & 0.008 & 0.450 \\
\hline Brazil & 1993 & 63.7 & 9.7 & 26.3 & 0.007 & 0.478 \\
\hline Brazil & 1995 & 56.3 & 9.4 & 25.2 & 0.008 & 0.470 \\
\hline Brazil & 1996 & 57.7 & 9.5 & 25.9 & 0.008 & 0.465 \\
\hline Chile & 1990 & 33.7 & 6.5 & 16.4 & 0.013 & 0.443 \\
\hline Chile & 1992 & 25.5 & 5.2 & 13.0 & 0.016 & 0.417 \\
\hline Chile & 1994 & 34.6 & 6.8 & 16.9 & 0.013 & 0.451 \\
\hline Chile & 1996 & 36.8 & 7.2 & 17.9 & 0.013 & 0.460 \\
\hline Colombia & 1991 & 46.8 & 7.5 & 19.0 & 0.010 & 0.469 \\
\hline Colombia & 1993 & 58.1 & 9.3 & 23.5 & 0.009 & 0.505 \\
\hline Colombia & 1995 & 40.5 & 7.6 & 19.2 & 0.011 & 0.460 \\
\hline Colombia & 1997 & 65.5 & 8.4 & 23.3 & 0.007 & 0.463 \\
\hline Colombia & 1998 & 53.3 & 7.7 & 20.6 & 0.009 & 0.461 \\
\hline Costa Rica & 1989 & 27.3 & 4.3 & 12.6 & 0.012 & 0.340 \\
\hline Costa Rica & 1991 & 25.1 & 4.3 & 12.4 & 0.014 & 0.342 \\
\hline Costa Rica & 1993 & 23.9 & 4.0 & 11.6 & 0.014 & 0.340 \\
\hline Costa Rica & 1995 & 24.3 & 4.1 & 11.7 & 0.014 & 0.342 \\
\hline Costa Rica & 1997 & 23.0 & 4.1 & 11.6 & 0.015 & 0.344 \\
\hline Ecuador & 1995 & 49.7 & 7.4 & 20.3 & 0.009 & 0.440 \\
\hline Ecuador & 1998 & 74.6 & 8.1 & 24.4 & 0.006 & 0.438 \\
\hline El Salvador & 1995 & 34.5 & 5.4 & 15.0 & 0.011 & 0.393 \\
\hline El Salvador & 1997 & 35.3 & 5.9 & 16.2 & 0.011 & 0.398 \\
\hline El Salvador & 1998 & 105.0 & 9.1 & 30.8 & 0.004 & 0.416 \\
\hline Honduras & 1989 & 44.2 & 7.9 & 20.6 & 0.010 & 0.455 \\
\hline Honduras & 1992 & 44.8 & 7.3 & 20.1 & 0.009 & 0.425 \\
\hline Honduras & 1996 & 34.0 & 6.2 & 16.5 & 0.012 & 0.409 \\
\hline Honduras & 1998 & 100.8 & 11.4 & 37.1 & 0.004 & 0.446 \\
\hline Mexico & 1989 & 32.9 & 6.3 & 15.8 & 0.013 & 0.436 \\
\hline Mexico & 1992 & 33.3 & 6.4 & 16.4 & 0.013 & 0.432 \\
\hline Mexico & 1994 & 32.4 & 6.3 & 16.0 & 0.013 & 0.431 \\
\hline Mexico & 1996 & 31.7 & 7.0 & 17.3 & 0.014 & 0.441 \\
\hline Nicaragua & 1993 & 63.2 & 8.6 & 24.9 & 0.007 & 0.438 \\
\hline Nicaragua & 1998 & 73.6 & 10.3 & 28.5 & 0.007 & 0.486 \\
\hline Panama & 1991 & 83.0 & 9.0 & 29.8 & 0.005 & 0.418 \\
\hline Panama & 1995 & 71.4 & 8.5 & 25.9 & 0.006 & 0.426 \\
\hline Panama & 1997 & 74.4 & 9.2 & 28.0 & 0.006 & 0.441 \\
\hline Paraguay & 1995 & 77.2 & 11.7 & 31.0 & 0.007 & 0.508 \\
\hline Paraguay & 1998 & 38.3 & 5.5 & 17.0 & 0.010 & 0.367 \\
\hline Peru & 1991 & 23.7 & 4.4 & 12.3 & 0.015 & 0.350 \\
\hline Peru & 1994 & 40.5 & 4.8 & 18.3 & 0.007 & 0.297 \\
\hline Peru & 1997 & 31.6 & 5.7 & 15.5 & 0.012 & 0.391 \\
\hline Uruguay & 1989 & 14.7 & 3.0 & 8.3 & 0.021 & 0.309 \\
\hline Uruguay & 1992 & 17.9 & 3.5 & 9.7 & 0.018 & 0.326 \\
\hline Uruguay & 1995 & 16.7 & 3.3 & 9.3 & 0.019 & 0.314 \\
\hline Uruguay & 1997 & 17.5 & 3.5 & 9.5 & 0.019 & 0.331 \\
\hline Venezuela & 1995 & 24.3 & 4.4 & 12.3 & 0.015 & 0.356 \\
\hline Venezuela & 1997 & 33.7 & 5.3 & 15.0 & 0.011 & 0.379 \\
\hline
\end{tabular}

